Psychology and Sexuality (Preaching to the Choir Special Issue)

Deadline December 20, 2018 (https://cpasogii.com/special-issue)

\title{
Cross-cultural perspectives of LGBTQ psychology from five different countries: Current state and recommendations
}

\author{
Alexander Moreno, Ph.D.1§, Ruben Ardila, Ph.D.2, Karyofyllis Zervoulis, Ph.D3, Juan A. Nel, \\ DLitt et Phil4, Earnest Light, Ph.D.5 and Line Chamberland, Ph.D.1 \\ 1 Department of Sexology, Université du Québec à Montréal (UQAM), Canada \\ 2 Department of Psychology, National University of Colombia \\ 3 Department of Psychology, BPP University, United Kingdom \\ 4 Department of Psychology, University of South Africa, South Africa \\ 5 Psychologist in private practice, Markham, Ontario, Canada.
}

$\S$ Address for correspondence:

Alexander Moreno, Ph.D.

Centre intégré universitaire de santé et de services sociaux du Centre-Sud-de-l'Île-de-Montréal

Notre-Dame Hospital

1560, Sherbrooke Street East

Montreal (Quebec) H2L 4M1

Deschamps Pavilion, 2nd floor, Wing F, Room: F-2148

Phone: (514) 413-8777, Ext. 23600

E-mail: jhon.alexander.moreno@umontreal.ca or jhon.moreno@mail.mcgill.ca 


\begin{abstract}
Lesbian, gay, bisexual, transgender and queer or questioning psychology (LGBTQ psychology) is a branch of psychology that promotes inclusiveness in theory and practice across the science of psychology, affirming the lives of people with different sexual orientations and forms of gender expression in a non-heterosexist and non-genderist perspective. This article highlights the historical development of LGBTQ psychology in the context of different realities for LGBTQ people in five different countries (Russia, Greece, Colombia, South Africa and the province of Quebec, Canada). Key experts on LGBTQ concerns report distinctive challenges they have faced when promoting LGBTQ rights and developing LGBTQ psychology (e.g., the pathologization and criminalization of sexual diversity, neglect on the part of authorities, and rejection from religious groups). Human and mental health sciences have played an important role in the blossoming of LGBTQ psychology. Cross-cultural narratives show that the recognition of lesbian and gay rights comes before the recognition of the rights of bi, trans, queer and questioning people. Various forms of homonegativity and transphobia still coexist even in countries that have established protections and rights recognition for LGBTQ people. We provide 15 strategies to help psychological organizations and psychologists around the world promote the development of LGBTQ psychology.
\end{abstract}

Keywords: LGBTQ, psychology, Russia, Greece, Colombia, South Africa, Canada, Quebec 


\section{Introduction}

Lesbian, gay, bisexual, transgender and queer or questioning psychology (LGBTQ psychology) highlights the presence and increasing validation and acknowledgment of research, theory and practice on LGBTQ concerns across the science of psychology (Burnes \& Stanley, 2017b; Clarke \& Peel, 2007). LGBTQ psychology is a branch of psychology concerned with the lives of LGBTQ people because mainstream psychology has centred on heterosexual and cisgender people (Clarke, Ellis, Peel, \& Riggs, 2010). To be fully comprehensive, psychology must examine the experiences of all individuals, and LGBTQ psychology has provided a needed inclusiveness to the field. LGBTQ psychology has a broader focus than the psychology of sexuality alone, as it addresses prejudice, discrimination, coming out, parenting issues, family concerns and identity development. LGBTQ psychology has evolved from lesbian and gay psychology to LGBTQ psychologies, leading to an important diversification of perspectives and approaches within the field. Inclusivity and intersectionality have allowed LGBTQ psychology to acknowledge the neglected realities of different people in psychology (e.g., bisexual relationships, sexual diversity and disability, race privilege and sexuality, and transgender and intersex realities, among others).

There is no international consensus regarding the use of the abbreviation LGBTQ and other variations (e.g., LGBTQIA+, LGBTQI, LGBTQI2, etc.). In some non-Western cultures, the acronym may not even be valid for describing sexual orientation, gender diversity, and the expression of non-heterosexual realities. Each country and culture has a different history supporting the inclusion or exclusion of different groups. As in previous international works 
(Moreno \& Das Nair, 2016), we have tried here to respect the use of several terms reflecting local differences in the conception of sexual orientation, gender diversity and expression.

Clarke et al. (2010) provide the following characteristics to define LGBTQ psychology: a) it is a branch of psychology that is affirmative of LGBTQ people, b) it aims to challenge prejudice and discrimination against LGBTQ people, c) it contests the privileging of heterosexuality in psychology and in the broader society, d) it encourages LGBTQ concerns as legitimate topics in psychological research, e) it promotes inclusiveness in research and practice within a nonheterosexist and non-genderist framework, and f) it provides a range of psychological perspectives on the lives and experiences of LGBTQ people and on LGBTQ sexualities and genders. This definition encompasses both research and practice issues and the objectives of LGBTQ psychology provide a specific contribution to the field of psychology and a larger contribution to society and communities.

LGBTQ psychology can be considered as transversal to psychological science. That is, it is not restricted to a specific area of psychology. Consequently, LGBTQ psychology can enrich the theoretical perspectives used within different areas of psychology. In addition, LGBTQ psychology is relevant to all aspects of professional practice. As such, "the practice of LGBTQ psychology is not confined to a particular therapeutic or exploratory method, it does not provide a framework for the assessment of competence or functioning, nor does it have as its goal the alleviation of pain or suffering though the application of various interventions" (Rivers, 2007, p. 332). 
Psychology and psychiatry hold a privileged role in science and society, allowing them to define what is normal and what is not, but this privilege brings with it a responsibility to fairness, both within and outside the profession (Glassgold \& Drescher, 2007). A psychology that is not affirmative of LGBTQ people provides a distorted picture of their lives. Although stigma has lessened over time, it is still present as part of a longstanding history of pathologization, and adds to mental health problems in the LGBTQ community (Matza, Sloan, Kauth, \& DeBakey, 2015). Currently, some professional psychological bodies affirm that LGBT people have a sexual orientation or gender identity that is normal, healthy and legitimate (Bidell, 2016; International Psychology Network for LGBTI Issues - IPsyNet, 2018; Ordre des Psychologues du Québec, 2012; Veltman \& Chaimowitz, 2014; Victor \& Nel, 2016, 2017; Victor, Nel, Lynch, \& Mbatha, 2014). However, this evolution has been dissimilar in different countries.

The lives of LGBTQ people outside the United States have been neglected in LGBTQ psychology, as the field and most of the researchers are US-based. A historical overview of the key issues and milestones at different stages of the evolution of LGBTQ psychology across the world is warranted. The objective of this article is to highlight the current state of development of LGBTQ psychology in five different countries: Russia, Greece, Colombia, South Africa, and the province of Quebec in Canada.

\section{Methods}

Information was collected by authors through direct contact with psychologists working in the countries listed above or belonging to psychological associations in these countries. Supporting 
literature (including grey literature) was consulted in different languages (Russian, Greek, Spanish, French, and English). The state of LGBTQ psychology is summarized in Table 1, which provides the following information by country: a) contextual information about the rights of LGBTQ people, b) the existence of laws penalizing LGBTQ people or the expression of sexual orientation or gender identity, c) a classification of the evolution of LGBTQ psychology (see the note following

Table 1), d) a description of the role of psychology in local LGBTQ issues, e) the role of the government in LGBTQ concerns, and e) future directions in LGBTQ psychology.

Based on the critical examination of the information collected, the authors describe the evolution and current state of LGBTQ psychology and provide a cross-cultural analysis and recommendations for developing and promoting LGBTQ psychology.

\section{Results}

As anticipated, LGBTQ psychology is at different stages of development in the countries listed in this study. The summary is presented in Table 1 .

\section{Insert Table 1 here}

Below, we include a short description for each country to provide more information about the sociohistorical context and the current state of LGBTQ psychology.
a) Russia 
Russia was part of the Union of Socialist Republics (USSR) from 1922 until it became an independent state in 1991. There are two important periods for LGBTQ communities in Russia. The first period, from 1991 to 1999, was characterized by growing social tolerance toward LGBTQ people. In 1993, male homosexuality was removed from the Russian Criminal Code, and in 1999, homosexuality was removed from the list of psychiatric disorders in Russia. The Russian LGBTQ movement was mainly driven by the advocacy of Igor Kon (1928-2011), the prominent sociologist and sexologist, who pioneered the study of homosexuality in scientific and social discourse (also known as duma (дума), Lunin, 2017). Queer activists also contributed to this process (e.g., Evgenia Dobryanska, Mila Ugolkova, Elena Gusiatinskaya, Masha Gessen, among others).

The second period, characterized by growing social intolerance towards the LGBTQ community, started in 2002 and continues in the present time. Until the mid-2000s, progress was being made and some scholars report a major crackdown in the late-2000s (Dufalla, 2010; Healey, 2002; Kondakov, 1993). The passage of the 2006 Russian NGO Law and the 2013 Foreign Act Law resulted in the dominance of state funded and controlled organizations, leaving numerous LGBTQ organizations under high vulnerability, scrutiny, and pressure (Horne \& White, 2019). The main event of this period was the proclamation of a law against the public expression of samesex relationships, which is framed as "gay propaganda", for the purpose of protecting children from information that advocates for a denial of traditional family values. This law (Propaganda Ban on Non-Traditional Sexual Relations), adopted in 2013, equates homosexuality with pedophilia. It led to an increase in violence against LGBT communities and was highly criticized by the international community (Horne \& White, 2019). In 2017, in a region of Russia named Chechnya, or officially the Chechen Republic, people who were suspected of belonging to LGBTQ 
communities were prosecuted, tortured and in some cases even killed by authorities (Shuster, 2018).

Since 2013, the situation of LGBTQ rights has deteriorated dramatically in Russia, and so has psychological research about LGBTQ issues. An example of the consequences of the Gay Propaganda Law illustrates these difficulties. On March 27, 2016, Dmitry Tsilikin, a Russian journalist, actor and educator, was murdered. When the man who murdered him was arrested, he explained that he considered himself a "cleaner," and that he had killed Tsilikin because he considered him to be gay. Dmitry Tsilikin (1961-2016) had published a very progressive book in two volumes about sexual education (Tsilikin, 2002). Tsilikin criticized the hypocrisy of conservative members of the Russian Parliament (Lunin, 2017).

In Russia, religion plays a big role in attitudes toward LGBTQ people. Orthodox Christianity is the main religion in Russia. The second one is Islam. Both of them are highly intolerant toward LGBTQ communities (Kon, 2003). With a gradual decline in democracy, stateowned mass media has declared LGBTQ individuals as a threat to traditional family values, saying that LGBTQ people promote immorality. New indicators that show intolerance of LGBTQ include the appearance of hate words such as "Gayrope" for Europe, the rise of violence against LGBTQ people and communities and the state's neglect to punish these crimes, and indulgence towards the Orthodox Church as it incites hatred of LGBTQ people (Rivkin-Fish \& Hartblay, 2014). 
It is nearly impossible to legally express disagreement with government policy toward LGBTQ people. Participation in any meeting against anti-LGBTQ discrimination is punished by extremely high fines or even by incarceration. "Consequent strengthening of repression diminishes activism because it makes the costs unbearably high" (Buyantueva, 2018). Concretely, the adoption of the 2013 law made LGBTQ activism illegal.

Studies on attitudes about homosexuality indicate that $37 \%$ of Russian people believe that homosexuality is a disease and 5\% that homosexuals should be liquidated (Levada Center, 2015). An important proportion of Russians believe that same-gender sexual relationships are unacceptable (Andersen, 2008). However, Muscovites tend to have more positive attitudes towards LGB people, as compared to people from Volgodonsk (Horne, Maroney, Zagryazhskaya, \& Koven, 2017). LGBTQ people have to leave Russia and seek asylum in other countries. For example, in 2017, thirty-one gay and bisexual Chechen men and women have been granted asylum in Canada following a violent crackdown on LGBT people in the Russian republic. They are being brought to Canada as part of an under-the-radar collaboration between human rights groups and the federal government (Murphy, 2017).

Horne and White (2019) describe that transgender people present high rates of discrimination for basic medical and community services. A report on the violation of transgender people's rights in Russia indicates that $62 \%$ choose not to change jobs or not to apply for an attractive job vacancy, $41 \%$ avoid seeing a doctor and using public health services, $34 \%$ choose not to go into university/school, $33 \%$ do not use bank services, $30 \%$ avoid intercity traveling, $27 \%$ choose not to get an international passport, $23 \%$ avoid foreign traveling, $21 \%$ choose not to get a driving license, 
and $19 \%$ avoid applying for a visa (Yashenkova \& Kirichenko, 2016). Currently, Russia has an unprecedentedly high level of intolerance towards LGBTQ people. No research is supported by state or private funding if it contains any mention of homosexuality. In 2013, psychologists worked towards opposing the gay propaganda law but were not heard by the government. Therefore, only few psychologists deal with LGBTQ issues in research, counselling, and education. These active and visible people include Dmitri Isaev (Isaev, 2016), Evgeni Osin (Gulevich, Osin, Isaenko, \& Brainis, 2018), Maria Sabunaeva and Hana Korchemnaya. Usually, there is no request from the government for any expertise in LGBTQ issues. However, the Russian Psychological Society (RPS) signed the IPsyNet Statement on LGBTIQ+ Concerns (IPsyNet, 2018). To our best knowledge, the psychological community in Russia is not aware of this statement and it has no influence on the majority of the country's psychologists; but it is hard to know for certain what its impact has been, given that it was released only recently and the Russian translation is not provided on the RPS website (RPS, personal communication, November 7, 2018).

\section{b) Greece}

Greece is a medium-sized Mediterranean country in the southeast corner of the continent of Europe, and it has been a member of the European Union (EU) since 1981. It is a relatively new independent country, a product of the nation-state ideology that preoccupied Europe in the 19th century, and a state that has existed in its current entity for no more than 100 years. Before its independence, for centuries it was a province of the Ottoman, Byzantine and Roman Empires. Its identity is built mainly on its inheritance of ancient Greek history (the Hellenistic period) and achievements, on its Christian Orthodox religion cemented by its Byzantine past, by its constant 
contact and interactions with both Middle Eastern and European ethnic and religious groups and civilizations, and by its recent political and cultural orientation, which is predominantly Western.

In ancient classical Greece, male same-sex sexual activities were quite common and were not seen as either problematic or shameful (Hoffman, 1980; Nussbaum, 2002). For example, male nudity and same-sex acts were common themes of respectable paintings and literature. In Athens particularly, the pattern was of a sexually passive lover (in terms of anal penetration), usually younger, who was the object of admiration of a sexually active lover, usually older, who provided friendship, education and political advancement. Such relationships were seen as playing an important function for inspiring and educating male youth (Percy, 2005). However, in the largely male-dominated Greek states of the era, women were governed by much stricter social regulations and were expected to safeguard the honour of the family by maintaining their own sexual purity. Still, there are some positive depictions of female-to-female erotic relationships within Spartan choral poetry and the poems of Sappho, the famous poet from the Greek island of Lesbos. In general, while we cannot claim the existence of what we would call a gay culture, there is evidence of a relatively positive view of homosexuality in ancient Greece.

On the other hand, like all monotheistic religions, Christianity contributed heavily to the stigmatization of LGBTQ people in Greece. Currently, the country has a highly religious population (Dianeosis, 2018) and prominent figures within the Greek Christian Orthodox Church still persist in openly expressing aggressively homophobic views (ToVima Team, 2018). Furthermore, Greece has chronically been a deeply patriarchal society steeped in strong traditional gender-typed roles. Adding to this, the importance that Greek society places on family and family 
honour contributes to the perpetuation of traditional heteronormative views and to the stigmatization of alternatives. Early pieces of research around Greek gay men and lesbians show that in context of the honour value system of the Greek family, if homosexual behaviour is found out or admitted to, the whole family is shamed (Fygetakis, 1997; Phellas, 2001). Such views resemble those common in other traditional, collectivistic societies in the Balkans, the Middle East and Latin America (Bereket \& Adam, 2006; Morales, 1996). Based on the above, it is not surprising that attitudes towards LGBTQ people in Greece are not as welcoming as those common in more Western members of the EU (European Commission, 2008). The recent findings of the seventh wave of the Greek section of the World Values Survey (Dianeosis, 2018) showed that $33.3 \%$ of those asked would not want to have a homosexual person as a neighbour.

Still, Greece has famous destinations that attract LGBTQ holiday-makers from all over the world, such as the island of Mykonos and Greece's capital, Athens, which is host to an increasingly vibrant and visible LGBTQ community. As well, cultural globalization is exposing many more Greeks to more liberal societies via travel, traditional media and social media, and the country's EU membership comes with cultural and legislative obligations towards respecting sexual minority groups. These influences may be contributing to the improvement of both societal views and institutional behaviours toward LGBTQ people. In combination with the recent election of a socially liberal, progressive political government, Greece is currently experiencing a sudden positive advance on LGBTQ issues. For many decades, with the exception of the law that decriminalized male homosexual acts in 1951 (note there was never legislation that referred to female same-sex sexual acts), Greek governments did not address any issues aiming to decrease discrimination against LGBTQ people. However, the second decade of the 21 st century has seen a 
sea change. Since 2015, same-sex couples can have legally recognized partnerships that give them similar rights to heterosexual civil marriages, and, as of 2018, they can adopt or foster children. In 2017, a new law allowed for people to change their legal gender as they wish and, since 2014, comprehensive laws have been passed to penalize hate speech and crimes aimed at LGBTQ people.

The role of vocal individual LGBTQ activists,, such as Gregory Vallianatos, and groups such as Athens Pride (www.athenspride.com), Thessaloniki Pride (www.thessaloninipride.com) and the Homosexual and Lesbian Community of Greece (OLKE; www.olke.org) have been significant if not crucial. The same is true of the role of publications such as Anti-Virus magazine (www.avmag.gr) and the online magazine 10 Percent (www.10percent.gr).

Psychologists working in Greece may have also played a role toward these changes, but this is difficult to determine. On one hand, some Greek psychologists have published papers in international peer-reviewed journals in psychology and related fields dealing with issues of homophobic attitudes and experiences of homophobia (Papadaki, Plotnikof, Gioumidou, Zisimou, \& Papadaki, 2015; Spiliotis, Brown, \& Coyle, 2011; Voultsos, Zymvragou, Raikos, \& Spiliopoulou, 2018; Zervoulis, Lyons, \& Dinos, 2015) as well as articles in places such as the online psychology journal Animartists (animartists.com). As well, psychology, counselling and therapy teams have been created to work with LGBTQ people and their families, such as the 11528 Dipla sou helpline (11528.gr) and the Orlando LBGT+ (facebook.com/orlandolgbt.gr/?_rdr) and

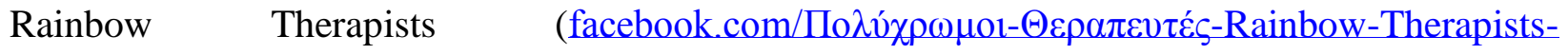
199802317094815/) teams. Additional relevant prominent psychologists and counsellors include George Brekoulakis, Leo Kalovyrnas, Michael Lardas and Eva Spinou. 
On the other hand, there is no formal section dealing with LGBTQ issues within Greek psychological societies and no formal guidelines or code of conduct for psychologists, counsellors and therapists working with LGBTQ people and their families (Zervoulis, 2016). This has been confirmed by several psychologists and therapists working in Greece. Still, regular educational programs have been developed by psychology academics with an interest in LGBTQ issues, and practising psychologists run seminars at the university level. Based on the proactivity of such academics and practitioners, there is clear hope that psychology will become a more integral part of the process of decreasing discrimination against LGBTQ people in the country and any mental health consequences that such discrimination may have on them. The development of relevant guidelines and a code of conduct, and of relevant recognized psychology groups and study programs, can contribute further toward responding to the needs and advancing the rights of LGBTQ people and their communities in Greece.

\section{c) Colombia}

Colombia is a country of 45.5 million inhabitants (DANE, 2018) located in northwestern South America. It has coasts on the Caribbean Sea and the Pacific Ocean. The main language is Spanish, and $92 \%$ of the population has been baptized Roman Catholic; $61 \%$ of the population affirms to be practicing Catholics. Colombia is a middle level developing country.

Homosexuality was a criminal offense in Colombia until 1980. The law condemned homosexuality in the Criminal Code with a jail sentence of five years or more, supposedly to fight 
against "immoral" practices. The first gay liberation movement in Colombia arose in Medellín, and it was led by León Zuleta (1952-1993). He was a young philosopher who gathered a group of people around him and had influence in literary, artistic and intellectual circles. He founded the Gay Liberation Encounter Group. Zuleta was a leftist anti-establishment thinker who considered that the gay liberation movement should begin with individual behaviour (meaning psychological liberation). The first gay magazine published in Colombia was entitled $\mathrm{El}$ Otro and came out in 1977 due to León Zuleta's work. It had a short life, as did Zuleta himself. He was killed at age 41 under strange circumstances, and with the passage of time he has become an iconic figure for the LGBT community.

Manuel Velandia founded the Colombian Homosexual Liberation Movement in 1976. The group collaborated with many initiatives, including the publication of books, magazines, and pamphlets. The next publication was entitled Ventana Gay. In addition, Velandia wrote several books that helped to make the Colombian LGBT community visible.

Colombia's first Gay Pride Parade took place in Bogotá on June 28, 1982, with very little participation. León Zuleta was one of its promoters. It is said that 32 people marched, many of whom had their faces painted so as not to be recognized. The march received only slight coverage from the mass media, but it was the starting point for the parade that later became an annual event. Pride parades have taken place in Bogotá since 1997 and in the city of Medellín since 1999. In other Colombian cities, parades started some years later and take place on days around June 28 (Gay Pride Day, the anniversary of Stonewall). They are colourful parades, with a party atmosphere, similar to many that are celebrated in cities around the world. The attendance is high 
and includes LGBT communities, heterosexual friends, parents, intellectual groups, politicians, commercial businesses oriented toward this population and so on.

In Colombia, homosexuality was traditionally treated as a sin, a criminal offense or a mental disease (Ardila, 2008, 2015). In the 1980s there were plenty of changes and shifts regarding the LGBT population in Colombian society. Several people took up the defense of sexual minorities, above all Germán H. Rincón Perfetti. He is a lawyer who became a spokesperson of the LGBT population and defended victims in court when they were being persecuted for their sexual orientation.

During that same decade, anti-gay movements arose and hate crimes occurred in Bogotá, Cali, Medellín, and other Colombian cities, involving attacks against individuals, gay bars, bathhouses, parks and other meeting places. The Catholic religion opposed the rights of the LGBT community. Just a few priests and a handful of Catholics defended these rights. The 1980s and 1990s were a period of great turmoil and many fluctuations in the situation of sexual minorities. Support groups were organized at the National University of Colombia, the University of the Andes, in several cities and within human rights organizations. One group that had a great impact is Colombia Diversa (http://colombiadiversa.org). Today, it is the main reference regarding sexual minorities in the country. Human rights, legal aspects, health, psychological support, education, fighting discrimination and related topics are part of its agenda.

Psychologists have conducted pioneer research in Colombia about transgender concerns (Talero, 1997, 2006, 2008) and the first psychological guidelines for lesbian, gay, and bisexual 
people form the America Psychological Association were translated into Spanish and published in a book about homosexuality and psychology (Ardila, 2008, 2015). Psychological organizations have been involved in LGBT concerns for several years. The Colombian psychological Society (1978-2014; Sociedad Colombiana de Psicología, SOCOPSI) appointed two international member representatives to IPsyNet (Ruben Ardila, 2001-2008; Alexander Moreno, 2009-2016). The Colombian College of Psychologists founded in 2006 (Colegio Colombiano de Psicólogos, COLPSIC) has recently appointed two representatives to IPsyNet (Miguel Rueda and Reynel Chaparro). COLPSIC has a division (or "disciplinary field" No. 9) named Psychology of Sexuality (see table 1). SOCOPSI coexisted with COLPSIC for several years and its president (RA, coauthor of this article) decided to close it in 2014 to allow only one main organization to represent the interests of psychologists in the country. A number of this Division's activities are centred on LGBT issues. On their website (http://www.colpsic.org.co), COLPSIC has released statements about adoption by same-sex partners. COLPSIC participates in the debates with the Ministry of National Education to promote inclusiveness in schools and also promotes the adoption of the Guidelines for psychological practice with lesbian, gay, and bisexual clients, as well as the Guidelines for psychological practice with transgender and gender nonconforming people in Colombian universities (COLPSIC, personal communication, March 14, 2019). COLPSIC is also partnering with US-based researchers (e.g., Sharon Horne) to study the attitudes of Colombian psychologists regarding LGBTQ concerns.

Other psychologists work in private practice offering services to the LGBT community including organizations such as LIBERARTE (Carolina Herrera and Simón Torres, https://www.liberarte.co/es/), PINK Consultores (Miguel Rueda, 
https://www.pinkconsultores.com), TRANS-SER (1995-2009; Marina Talero Monroy, https://lib.ohchr.org/HRBodies/UPR/Documents/Session3/CO/TRANS-

SER_COL_UPR_S3_2008_ReddeApoyoaTransgeneristas_uprsubmission.pdf), and the first community service for LGBTI people in Colombia and Latin America (Centro Comunitario LGBTI, http://ccdlgbt.blogspot.com; Ángela Bejarano) offering not only psychological services but also legal advice and information. COLPSIC's current president has conducted research in transgender individuals (Gonzáles, Ardila, Guerrero, Penagos, \& Useche, 2004; Useche, 2005a, 2005b).

Much progress has been made in the last few years in Colombia. Same-sex marriage (equal marriage) has been legal since April 28, 2016. Same-sex couples have also been able to legally adopt children since November 3, 2015. There is a national public policy for LGBTI people living

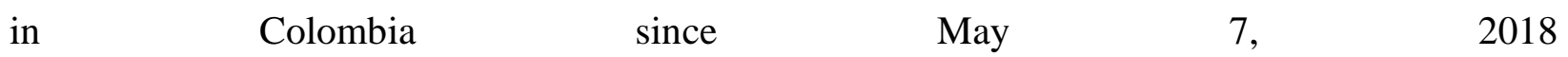
(https://www.mininterior.gov.co/sites/default/files/decreto_762_politica_publica_garantia_de_lo s_derechos_sectores_sociales_lgbti.pdf). This policy contains information about the promotion of the rights of LGBTI people in Colombia (e.g., education, health), promote participation in society and access to the workforce, healthcare, culture, and education. Society is more tolerant, and hate crimes have been reduced. Still, despite these advances, there is still a long way to go toward a fully equal society in which sexual and gender minorities are respected and integrated into mainstream life.

d) South Africa 
In the 21 st century, it still remains challenging to advance our understanding of sexual and gender diversity, including lesbian, gay, bisexual, transgender, intersex, queer and asexual people (hereafter LGBTIQA+). Nowhere is this more evident than in Africa, where in 2017, 33 of the continent's 54 countries had laws criminalizing same-sex sexual acts, some imposing the death penalty and many with sentences of 10 years of imprisonment (International Lesbian, Gay, Bisexual, Trans and Intersex Association, or ILGA, Carroll, \& Mendos, 2017). On the African continent, non-conforming gender identity and expression is legal in only one country, South Africa (ILGA, Chiam, Duffy, \& González Gil, 2017).

In democratic South Africa, born in 1994, human rights are deemed universal, indivisible, interdependent and interrelated, at least on paper. Accordingly, LGBTIQA+ rights are considered human rights, affording this country international recognition for its progressive constitution that was the first to include non-discrimination on the basis of sexual orientation (Hoad, Martin, \& Reid, 2005; Republic of South Africa, 1996). In 2006, it also became the fifth country in the world, and the first in Africa, to allow same-sex marriage (Judge, Manion, \& De Waal, 2008).

Still, regardless of South Africa proverbially being "a 'rainbow' that, indeed, is visible on the world stage" (Nel, 2014, p. 145), it is important to note that a discriminatory mindset remains deeply embedded in the psyche of this highly patriarchal, hetero- and cis-normative society and that experiences of prejudice and violence against a diverse range of "others" is not at all rare (Mitchell \& Nel, 2017; PsySSA, Nel, Lubbe-De Beer, \& Schlittler, 2010). In light of apartheid South Africa's well-known history of institutionalized discrimination and other human rights abuses in which psychology, too, was complicit (PsySSA et al., 2010; PsySSA, Nel, Lubbe-De 
Beer, \& Schlittler, 2011), it should come as no surprise that the battle continues in everyday life, in general, and in public healthcare, specifically, against the invisibility and societal marginalization of sexually and gender-diverse people and communities.

LGBTIQA+ advocacy in South Africa dates back only to the early 1980s. This brief history is suggestive of how oppressive the previous political regime was (De Waal \& Manion, 2006; Gevisser \& Cameron, 1995; Hoad et al., 2005). The first volunteer-driven civil society organizations (CSOs) with an LGBTIQA+ psychosocial or healthcare component to their work also only came about in the early to mid-1980s (De Waal \& Manion, 2006; Hoad et al., 2005). CSOs are often less formal than non-governmental organizations and are typically communitybased (Moeti, 2012). Within the South African context, CSOs and civil society, in general, have been reinvented since the start of the democratic dispensation in that they became associated with new social movements grounded in the principles of equality and liberalism (Magongo, 2016). Individual pioneering psychologists were involved in these initiatives in Johannesburg and Cape Town, and a number of volunteers went on to become psychologists themselves, of which some remain involved in LGBTIQA+ psychology today. Shortly before the advent of democracy in 1994, some limited research into sexually and gender-diverse people and communities began to emerge, but not in the field of psychology (Isaacs \& McKendrick, 1992; Reddy, Sandfort, \& Rispel, 2009; Van Zyl \& Steyn, 2005). Today, despite the continued lack of funding for the study of sexuality and gender, there is a small but growing body of work that constitutes South African LGBTIQA+ psychology (Nel, 2009a, 2009b; Odendaal \& Nel, In Press; PsySSA, 2013; Victor et al., 2014). This scholarly work, mostly informed by practice, builds on the important foundations laid and documented by a handful of LGBTIQA+-focused CSOs in South Africa that provide 
(psychosocial) health services. A majority of today's groups emerged with the dawn of democracy; most notably, they include Triangle Project (www.triangle.org.za), the Anova Health Institute (www.anovahealth.co.za) and OUT LGBT Well-being [OUT] (www.out.org.za). In addition, related psychology-informed research and continuing professional development (CPD) offerings to healthcare providers are provided by only a few universities, one of which is the University of South Africa Department of Psychology and its Centre for Applied Psychology (UCAP) in collaboration with OUT (Judge \& Nel, 2007; Nel, 2004; Nel \& Judge, 2008; Odendaal \& Nel, In Press; UCAP, 2008).

With an understanding that the historic silencing of sexually and gender-diverse people, including within South African psychology, is not just a human rights issue but also a (mental) health concern, in recent years there have been several relevant developments in South African organized psychology. These developments are rapidly accelerating. PsySSA, in particular, as the largest and most nationally representative psychological association, is striving to undo the harms of the past and to move toward a psychology that serves all (Nel, 2014; PsySSA, 2010). PsySSA has begun to play a critical role in related national and regional initiatives. Since 2007, PsySSA has been a member of IPsyNet, a network that facilitates and supports the contributions of psychological organizations to improved health, well-being and enjoyment of human rights by promoting policy, education and advocacy for sexually and gender-diverse people globally (IPsyNet, 2018). One example of how the network is trying to affect public education and policy is by providing technical assistance to national psychological associations, such as with the public statement issued by PsySSA in February 2010 opposing the anti-homosexuality legislation that had been introduced in the Ugandan national legislature (APA, 2010; Nel, 2014). The 
internationally funded PsySSA African LGBTI Human Rights Project has been most beneficial in accelerating LGBTIQA+ psychology, among others through the establishment of the PsySSA Sexuality and Gender Division in 2013 (Nel, 2014, 2018; UCAP, 2008).

As evident from Table 1, PsySSA, among other initiatives, has embraced an affirmative stance on sexual and gender diversity with a related position statement (Nel, 2014; PsySSA, 2013; Victor $\&$ Nel, 2016, 2017; Victor et al., 2014) and practice guidelines (Nel, 2018; PsySSA, 2017) that are uniquely (South) African and the first and only such initiatives for the continent. PsySSA served as amicus curiae in a high-profile homophobic hate speech case (Judge \& Nel, 2017) and also issued a range of open statements in response to domestic developments. The list includes responses to developments in the religious sector (Nel, 2008; PsySSA, Nel, \& McLachlan, 2018); a statement against the stand of South African representatives who voted to remove a reference to sexual orientation from a United Nations resolution on extrajudicial, summary and arbitrary executions and other killings (PsySSA et al., 2010); and a regional response to the anti-gay developments in Uganda (APA, 2010; Nel, 2014; PsySSA et al., 2010). In this manner, PsySSA is shaping public discourse and policy, extending beyond South Africa - and beyond the field of psychology - to elsewhere on the African continent and to other disciplines. This is evident, for instance, in PsySSA's participation in the Academy of Science of South Africa (ASSAf) consensus study, challenging scientists in Africa to engage more actively in research to reduce stigma and work to promote access to affirmative healthcare and educational materials for sexually and gender-diverse people and communities (ASSAf, 2015). 
The South African developments mentioned here are glaringly out of step with the rest of the continent, where psychology is underdeveloped, silent or actively supportive of the oppressive political mainstream, and where decision-maker de-prioritization and healthcare provider neglect remain the norm for sexually and gender-diverse people. Given this state of affairs, South African psychology is keen to foster regional participation in related debates and help grow an indigenous knowledge base.

\section{e) Quebec (Canada)}

Remembering the past struggles of the LGBTQ movement for legal and social equality is essential if we are to recognize the contribution of older generations to societal change. Homosexuality was partially decriminalized in 1969 in Canadian criminal law. That decriminalization referred to homosexual acts committed between consenting adults in private spaces. During the 1970s and 1980s, gay men and lesbians mobilized around separate issues. For gay men in major cities such as Montreal and Toronto, fighting against police repression was the most central issue during these decades. While coming out was still a risky choice for both gays and lesbians, who suffered from everyday discrimination and rejection by their family and friends, lesbians specifically were confronted with the social invisibility of lesbianism, the absence of cultural references, words with which to identify themselves and places to meet (Chamberland, Lévy, Kamgain, Parvaresh, \& Bègue, 2018). In 1977, Quebec became the first province to amend its Charter of Human Rights and Freedoms to prohibit discrimination on the basis of sexual orientation. Over the next 20 years or so, sexual orientation was added to the list of prohibited grounds in all provincial and federal charters and human rights codes (Chamberland et al., 2010). 
By the end of the 1980s and increasingly during the 1990s, political issues began to be defined differently. The most influential cause that mobilized gay men was the impact of the HIV pandemic, which amplified feelings of being stigmatized, discriminated against and isolated. The illness and the death of partner and friends were particularly distressing moments that revealed emotional, social and economic injustices. For example, parents who had rejected their gay sons sometimes laid claim to their belongings after they died (even if they had been jointly purchased with a partner), refused to allow partners to attend funeral services, or otherwise shut friends and lovers out. Same-sex couples weren't socially or legally recognized. For lesbians, fighting for the recognition of their parental role was an important issue. Lesbians who had become mothers in a heterosexual marriage risked losing custody of their children if they chose to live with another woman after their divorce. Lesbian couples who wanted to create their own families faced many difficulties: no access to fertility clinics, no legal recognition for the "social mother" (the term then used to refer to a child's non-birth mother), lack of protection for the child who was considered as having only one parent (Chamberland et al., 2018).

Over the course of that decade, gays and lesbians began to mobilize around issues related to discrimination in all areas; for example, they fought for access to the same financial and social advantages offered to straight couples by law or by their workplaces' collective agreements. Struggles against all forms of discrimination focused on issues of legal recognition of couples and families and on non-discrimination in access to public services and other areas. New strategies were adopted, mixing media use, litigation, Pride marches and traditional lobbying, in order to force the federal and provincial governments to change their policies and practices. Broad alliances were made with civil society groups, including unions, as well as with academic researchers, 
including psychologists who were developing new fields of research around LGBTQ issues and whose expertise was particularly helpful in courts, public hearings and in the media (Fortier \& Julien, 2003).

Since 1992, Dr. Danielle Julien has played a key role in the development of psychological research about issues concerning same-sex couples and LGBT families (Julien \& Chartrand, 1997). De facto same-sex couples gradually gained legal recognition at the provincial and federal levels; family ties between a child and their two mothers or fathers were recognized in Quebec in 2002; and access to marriage was progressively granted by court decision in Ontario and other provinces beginning in 2003 until the federal legislation was modified in 2005 (Smith, 2011; Tremblay, 2015). Compared to France, Quebec psychologists appear to be more supportive of gay- and lesbian-headed families and of their legal recognition (Vecho \& Schneider, 2015).

Since its initial appearance in Quebec, LGBT psychological research has focused on sexual orientation, well-being and mental health (Julien \& Chartrand, 2005), on the relationships between LGBT youth and their parents before and after their coming out (D'amico, Julien, Tremblay, \& Chartrand, 2015), on same-sex couples and LGBT families (Julien, 2008; Vyncke, Julien, Ryan, Jodoin, \& Jouvin, 2008), more specifically on the experiences of lesbian mothers, and more recently, of gay fathers (Feugé, Cossette, Cyr, \& Julien, 2019) and trans parents (Petit, Julien, \& Chamberland, 2018), on the psychological development of kids raised in those families and the difficulties faced by them when they reach adolescence, especially in schools (Vyncke, Julien, Jouvin, \& Jodoin, 2014). 
The contemporary period is characterized, on the one hand, by the institutionalization of the LGBTQ movement and, on the other hand, by the diversification of political and ideological concerns, which has led to internal dissension between so-called radical and assimilationist tendencies. A series of "new" issues have begun to receive attention, including bullying in schools and other difficulties faced by queer youth; trans issues, particularly discrimination in access to health services and the absence of legal recognition; issues specifically concerning LGBTQ immigrants and refugees; distinct forms of discrimination against racialized LGBTQ people; and the legal recognition of multi-parent families, among others.

In Quebec, there is not a specific training program at the graduate level for LGBTQ issues. LGBTQ concerns are mainly addressed in psychology and sexology programs. The Chair (Chaire de Recherche sur l'homophobie) does not provide training in LGBTQ issues but it participates in the dissemination of the research done in psychology via a monthly newsletter or with the organization of interdisciplinary conferences. However, there are training opportunities in LGBTQ concerns provided outside the university. For instance, the National Institute of Public Health (https://www.inspq.qc.ca/formation/institut/itss) or the Institute for sexual minority health (https://en.ismh-isms.com) provided by Françoise Susset, psychologist (Susset, 2014, 2018), and Bill Ryan, social worker (Brotman, Ryan, Jalbert, \& Rowe, 2002). Denise Medico is developing training for clinical care for trans people (Medico, 2016). The role of the Chair is to facilitate a network of interdisciplinary researchers, including partner organizations to publicize their work.

In 2012, the Quebec College of Psychologists issued a position statement against conversion therapies (Ordre des Psychologues du Québec, 2012). Psychological research continues to play an 
essential role in social progress by demonstrating the concrete and persistent inequalities faced by different subgroups among LGBTQ communities and their impact on physical and mental health (Canadian Psychological Association, 2018; Weir \& Piquette, 2018). Over the last decade, trans rights have been recognized by most provincial charters of rights and by federal legislation that forbids discrimination based on gender identity and gender expression, but greater social recognition still remains to be gained.

Psychologists in Quebec collaborate with different Canadian research teams as well as with the Canadian Psychological Association (CPA) and its Sexual Orientation and Gender Identity Section created in 2002 whose mission is to advance knowledge and understanding of LGBTQ issues in psychology and allied disciplines (www.sogii.ca). The SOGII section also organizes preconferences on LGBTQ issues preceding yearly conferences of the CPA and gives annual students award. The CPA has supported the legalization of same-sex marriage in Canada in 2005 and positioned itself against conversion and reparative therapy. At their 2018 annual convention, the CPA has endorsed the IPsyNet position statement and commitment.

\section{Discussion}

We described the current state of development of LGBTQ psychology in five different countries (Russia, Greece, Colombia, South Africa and the province of Quebec, Canada). We identified distinctive challenges faced when promoting LGBTQ psychology in different countries (e.g., pathologization and criminalization of sexual diversity, authorities reluctance to prosecute anti-LGBTQ hate crimes, rejection from religious groups, homonegativity and transphobia, 
discrimination, victimization, microaggressions, and lack of support from mental health organizations and the government). Based on the dissimilar evolution of LGBTQ psychology in the five countries, we suggest different avenues to facilitate the emergence and consolidation of LGBTQ psychology. As psychologists, we recognize that "LGBTQ psychologies of all varieties help to support social change" (Clarke \& Peel, 2007, p. 1). It is our scientific and professional responsibility to increase the understanding of LGBTQ psychology across the world and to reduce social inequalities.

Over the last two decades, LGBTQ psychology has received increased recognition as a vital field of study within psychology (Riggs, 2013). Just recently, the first international conference on the topic was held in Lisbon in 2013 and the second in Rio de Janeiro in 2016. Also, the international meeting on LGB concerns in psychology in San Francisco in 2001 that launched IPsyNet. Psychologists have the science, tools and skills to advocate in various ways as content experts, role models and observers in regard to LGBTQ issues (Stevenson, 2005). As such, psychologists can help diminish the influence of heterosexist norms by creating awareness about privilege and stigma; influence the educational development of all health and mental health professionals with the promotion of inclusiveness and cultural competency; be affirming in their own work with clients, trainees and research participants to increase their satisfaction; and belong to and encourage the work of LGBT-affirming professional organizations to remove barriers and increase access to support services.

Of the five countries included in this study, only Greece has not signed the IPsyNet document, which represents a growing global consensus of professional authority grounded in 
psychological science concerning sexual and gender minorities; the document has been signed by 25 psychology organizations across the globe (IPsyNet, 2018). But global consensus and practice do not evolve at the same pace (Moreno, Herazo, Oviedo \& Campo-Arias, 2015). For instance, the consensus does not seem to have an impact on the practice of psychologists in Russia, even though Russia's main psychological organization supports it. However, a special edition of Psychology in Russia: State of the Art was published in 2017 under the theme "Psychology of sexual and gender identity," and the XVI European Congress of Psychology, to be held in Moscow in 2019, will include LGBTQIA+ programming. Contextual barriers may prevent the development of LGBTQ psychology; international advocacy is important toward promoting evidence-based practice and inclusiveness.

\section{Recommendations}

As scientist-practitioners, we can engage in responsible action that contributes to social justice and the elimination of oppression (Cochran \& Robohm, 2015). LGBTQ psychology can benefit from the perspective of social justice to dismantle cultural marginalization and cultural privilege by the application of multicultural knowledge, attitudes and awareness to create systemic change (Burnes \& Stanley, 2017a). Different strategies can potentiate the emergence of what in some countries is still an "invisible college" (Curtin, Hegarty, \& Stewart, 2012). Readers will be able to appreciate that the recommendations are not universal and that each country has to adapt them to their own realities. We can contribute to systemic change at different levels for trainees, professionals and institutions by putting in practice the following recommendations.

1. Create a Sexual Orientation, and Gender Identity and Expression (SOGIE) division, section or special interest group within the main regional psychological body to foster 
research, education, training and policy on LGBTQ concerns (Moane, 2013). Extending one-year free membership invitations to members of another division can help to disseminate the work of the special interest group, increase the diversity of members and bring in new voices and participation (Noriega, 2012). Some important examples are the establishment of division 44 of the American Psychological Association in 1984, the Gay and Lesbian Issues and Psychology Interest group of the Australian Psychological Society in 1994, the Psychology and Sexualities Section (formerly known as Lesbian and Gay Psychology section) of the British Psychological Society in 1998, the Section on Sexual Orientation and Gender Identity of the Canadian Psychological Association in 2002, the LGBT Psychology Special Interest Group of the rom the Psychological Association of the Philippines (PAP), and the PsySSA Sexuality and Gender Division in 2013.

2. Teach the history of LGBTQ psychology. Teaching this material is important to help the profession understand the influence of religion, laws, and evolving diagnostic categories regarding sexual orientation and gender identity (Stanley, Burnes, \& Weinstock, 2017). The history of LGBTQ psychology can help people to understand the influence of the past on current attitudes and behaviours toward LGBTQ people, including misconceptions, prejudice and discrimination. Historical views are important for reflecting on stereotypes, power, privilege and oppression in order to promote personal and professional understanding of LGBTQ issues. Universities offer courses on the history of psychology, mostly at the undergraduate level. The history of LGBTQ psychology could be integrated within the general content of the history of psychology. 
3. Within psychology programs, help to fill a theoretical and training gap by providing incentives to explore LGBTQ issues in different areas of psychology (e.g., include openness to exploring LGBTQ concerns in course objectives and allow students to focus on LGBTQ issues in their research). In this regard, Southern Africa has indeed seen an increase in publications addressing the need for more inclusive pedagogical and research practices, aimed at challenging heteronormativity (Francis \& Msibi, 2011; Nduna, Mthombeni, Mavhandu-Mudzusi, \& Mogotsi, 2017; Nel, 2009b).

4. Include LGBTQ issues in different areas of psychology to broaden perspectives and promote inclusiveness. This can be done in areas such as sports psychology (Lucas-Carr \& Krane, 2011; Mattey, McCloughan, \& Hanrahan, 2014; Shang, 2013), organizational psychology (Anderson \& Croteau, 2013), school psychology (Betts, 2013; Russell \& Horn, 2017; Salazar, 2015; Whitman, Horn, \& Boyd, 2007), positive psychology (Lytle, Rodriguez, Vaughan, \& Shmerler, 2014; Meyer, 2014; Vaughan et al., 2014; Vaughan \& Rodriguez, 2014), counselling psychology (Malouf, 2013; Walinsky, 2013), community psychology (Wheeler, Mitchell, Budge, \& Hunt, 2017), health psychology (Schlittler, Grey, \& Popanz, 2017; Ussher, 2009; Wallace \& Santacruz, 2017a, 2017b, 2017c) and neuropsychology (Moreno, Laoch, \& Zasler, 2017).

5. Create interdisciplinary graduate programs focusing on LGBTQ concerns. This can help to prepare future generations to improve the quality of services targeting LGBTQ people. For instance, George Washington University created the LGBT Health Policy and Practice Program, a graduate-level interdisciplinary certificate program in LGBT health, in order to mitigate LGBT health disparities and to adequately train LGBT practitioners in LGBT health (Forsell et al., 2017). 
6. Include LGBTQ issues in the curricula of training programs. Suggestions on how to address this need have been proposed (Brodnicki \& Savage, 2004; Weinstock, 2003). To enhance student learning, curricular developments must emphasize an intersectional pedagogical approach to situate LGBTQ psychology within the matrix of oppression including multiple social inequalities (Case \& Lewis, 2012; Wallace \& Santacruz, 2017d; Warner \& Shields, 2013).

7. Use online education to deliver LGBTQ psychology content with the advantage of accommodating different learning styles. Although efforts have been made to improve psychologists' knowledge and cultural competency, there are gaps in training. Online education can be a useful strategy toward closing these gaps. Content needs to be available in different languages to reach a wide audience. For instance, webinars have been successfully used to deliver educational content on LGBT healthcare (Matza et al., 2015).

8. Include LGBTQ concerns to help improve pedagogical practices in higher education, so that lecturers and professors have the tools to support clinical trainees and communities receiving psychological services (Burnes \& Stanley, 2017b). Sometimes, trainees experience conflicts between professional and personal values when they work with LGBTQ clients (Paprocki, 2014). Practicum training clinics need to include LGBTQ clients to help trainees to improve their competency. Conversations in a respectful classroom environment that facilitate dialogue about potentially sensitive topics and encourage trainees to examine their own biases, beliefs, privileges and blind spots can improve LGBTQ competency (Cochran \& Robohm, 2015). The interest of students and 
trainees in sexuality issues extends to supporting LGBTQ people with diverse life stories (Curtin, Hegarty, \& Stewart, 2012).

9. Increase cultural competency with LGBTQ individuals as an ongoing process over the course of one's career. Some authors have developed recommendations in this direction (Boroughs, Bedoya, O'Cleirigh, \& Safren, 2015). As the concept of culture has broadened to include sexual orientation and gender identity and expression (Burnes \& Stanley, 2017a), it is not limited to only race and ethnicity. The use of culturally sensitive language, sensitivity to confidentiality concerns, and learning about the effects of sexual minority stress are some examples of recommendations to increase cultural competence.

10. In psychotherapy, interrogate the pertinence and validity of our measures in sexual and gender minority populations to include proximal and distal stressors, positive coping and resilience, and the working alliance (Budge, Israel, \& Merrill, 2017).

11. Recruit and retain sexual minority students and faculty to ensure that the clinical and research interests will be supported in terms of mentoring and institutional support (Hope \& Chappell, 2015). The inclusion of faculty and students who identify as lesbian, gay, or bisexual is a key component of a program that has strong multicultural training (Biaggio, Orchard, Larson, Petrino, \& Mihara, 2003; Newell et al., 2010) and because the greater the diversity among the faculty, the more likely students from underrepresented groups will be attracted to a program (Hope \& Chappell, 2015).

12. Publish a specialized journal focusing on LGBTQ psychology to allow students and researchers to disseminate the results of their studies. Sometimes, given the specialized nature of LGBTQ psychology, these works are not published when they are submitted to less specialized journals. There are several peer-reviewed journals publishing in 
languages other than English, such as Polish (InterAlia: a journal of queer studies), German (Jahrbuch für die Geschichte der Homosexualitäten, Yearbook for the History of Homosexuality - annual thematic journal), Finnish (SQS: Journal of Queer Studies in Finland), Swedish, Norwegian, and Danish (Lambda Nordica), just to name a few. Special issues on LGBTQ psychology published in mainstream journals can also increase the exposure of more readership to this literature (e.g., the special thematic edition of Psychology in Russia: State of the Art entitled "Psychology of Sexual and Gender Identity" published in 2017).

13. Create summer schools to allow trainees to quickly get an immersion in different LGBTQ psychology developments and to develop research collaborations and ideas. Summer school experiences in Asia have reported successful results ("Kimmel Lectures on LGBT Psychology in China," 2005). A more recent example comes from the $31_{\text {st }}$ International Congress of Psychology in Japan where there has been extensive programming on LGBTQ concerns, including a whole section presented in Japanese (Moreno, Koch, \& dickey, 2016).

14. Create awards for accomplishments in LGBTQ psychology (APA, 2016; Balsam, 2016; Pope, 2011). Stimulating the work of students, early-career psychologists and researchers in LGBTQ psychology can help to consolidate emerging areas in LGBTQ psychology and motivate individuals to engage with the field.

15. Publish newsletters describing different activities and accomplishments of LGBTQ psychology to highlight the work of individuals and organizations, promote the development of working groups and facilitate communication.

Limitations and future directions 
Although we described the current state of development of LGBTQ psychology in five different countries, this number is small. As such, the results are a call to action for other researchers and scholars from different countries to engage in this discussion. As we did not include an Asian country, we invite the readers to read a comprehensive overview of the programming on LGBTQ concerns for the 31st International Congress of Psychology in Japan (Moreno, Koch, \& dickey, 2016). Also, it is possible that some of the conclusions we have reached or recommendations we have made may not apply to other specific contexts. In addition, we recognize that in various countries, there is a wider representation of gay and lesbian research, as compared to research on bisexual, trans and queer populations. The quantity and quality of psychological research on bisexuality is still low (Pollitt, Brimhall, Brewster, \& Ross, 2018). This is a very promising area as bisexual people are one of the fastest growing groups within in the LGBTQ community (Copen, Chandra, \& Febo-Vazquez, 2016). More research is needed on the lives of trans and queer people. Also, we did not explicitly address intersex people. As the coerced sterilization of and surgery on intersex people persists, more research and support is needed to address these realities from psychological perspectives (IPsyNet, 2018).

A common critique of LGBTQ psychology is that it is biased mainly toward describing the experiences of younger, white, middle-class, able-bodied, urban-dwelling gay men and lesbians (Clarke et al., 2010). We hope our current findings will contribute to overcoming important gaps in knowledge about LGBTQ people who are based outside of the US. However, the realities of LGBTQ individuals who experience heterosexism and social marginalization based on race, culture, gender, old age, disability, rural isolation, social class and poverty still need to be documented in non-Western cultures. As such, the current article is an attempt to provide different 
views from countries experiencing diverse social challenges. But we have not addressed any of the specific intersections listed here. We encourage researchers and scholars working in LGBTQ psychological research to investigate realities different from those of privileged groups. "It is very important to work through the hyphens that separate and connect sexuality, gender, race, culture, class, age, and ability as non-white, LGBTQ individuals with disabilities, and working-class LGBTQ people and white, 'abled' and middleclass LBTQ women are often doubly marginalized in psychology" (Clarke \& Peel, 2008, p. 12). LGBTQ psychology around the world will be key to developing knowledge in these areas.

\section{Conclusion}

In this paper, we have provided insight into the development of LGBTQ psychology in five different countries. We must allow comparisons and collaborations between countries in order to recognize the cultural and national specificities of LGBTQ lives and, in turn, lead to a truly international approach to LGBTQ psychology (Clarke et al., 2010). This article is a step in that it proposes specific recommendations to facilitate the emergence of LGBTQ psychology and to help the field develop in countries where it is already established as a formal area of psychological science. 


\section{Acknowledgments}

We would like to thank George Brekoulakis, Alkis Ioannidis and Leo Kalovyrnas for providing important information and knowledge in relation to the Greek context. We would also like to thank Christine Médaille (UQAM librarian), who helped to perform the literature review about LGBTQ psychology. As well, we thank the Chaire de Recherche sur l'homophobie (UQAM) and Andrea Zanin for reviewing the quality of the English language. 
Table 1. State of LGBTQ psychology in five different countries

\begin{tabular}{|c|c|c|c|c|c|c|}
\hline Country & $\begin{array}{l}\text { Rights of } \\
\text { LGBTQ } \\
\text { people }\end{array}$ & $\begin{array}{c}\text { LGBTQ } \\
\text { penalization }\end{array}$ & Classification & $\begin{array}{c}\text { Role of } \\
\text { psychology in } \\
\text { LGBTQ issues }\end{array}$ & $\begin{array}{l}\text { Government } \\
\text { involvement }\end{array}$ & $\begin{array}{c}\text { Future } \\
\text { directions }\end{array}$ \\
\hline Russia & $\begin{array}{l}\text { 1993: Sex } \\
\text { between men } \\
\text { became legal } \\
\text { 1998: } \\
\text { Homosexuality } \\
\text { not considered } \\
\text { as mental } \\
\text { pathology } \\
\text { Currently, same } \\
\text { sex marriage is } \\
\text { not allowed, } \\
\text { and same sex } \\
\text { couples may } \\
\text { not adopt } \\
\text { children. }\end{array}$ & $\begin{array}{l}2013 \text { - Any } \\
\text { mention of same- } \\
\text { sex relationships } \\
\text { could be } \\
\text { considered as an } \\
\text { offence. }\end{array}$ & $\begin{array}{l}0 \text { (Although } \\
\text { the Russian } \\
\text { Psychological } \\
\text { Society has } \\
\text { signed the } \\
\text { IPsyNet } \\
\text { statement } \\
\text { (IPsyNet, } \\
\text { 2018)) }\end{array}$ & $\begin{array}{l}\text { In 2017, RPS } \\
\text { published a } \\
\text { special } \\
\text { thematic } \\
\text { edition of } \\
\text { Psychology in } \\
\text { Russia: State of } \\
\text { the Art entitled } \\
\text { "Psychology of } \\
\text { Sexual and } \\
\text { Gender } \\
\text { Identity." }\end{array}$ & $\begin{array}{l}\text { LGBTQ } \\
\text { discourse is } \\
\text { considered as } \\
\text { an ideological } \\
\text { intervention on } \\
\text { the part of } \\
\text { enemies from } \\
\text { Europe and } \\
\text { North America. }\end{array}$ & $\begin{array}{l}\text { The only area of } \\
\text { research that is } \\
\text { not completely } \\
\text { prohibited is } \\
\text { related to gender } \\
\text { issues. } \\
\text { Research on } \\
\text { LGBTQ issues is } \\
\text { out of the } \\
\text { question. }\end{array}$ \\
\hline Greece & $\begin{array}{l}\text { 1951: De- } \\
\text { criminalisation } \\
\text { of male same- } \\
\text { sex sexual acts } \\
\text { 2015: } \\
\text { Recognition of } \\
\text { same-sex civil } \\
\text { partnerships } \\
\text { (cohabitation } \\
\text { agreement) }\end{array}$ & $\begin{array}{l}2014: \\
\text { Amendment of } \\
\text { law against } \\
\text { racism to include } \\
\text { fines or } \\
\text { imprisonment for } \\
\text { discrimination } \\
\text { and hate crimes } \\
\text { against LGBT } \\
\text { people } \\
\text { 2015, 2016: A } \\
\text { series of strong } \\
\text { anti- }\end{array}$ & $\begin{array}{l}0 \text { (Although } \\
\text { practising } \\
\text { mental health } \\
\text { professionals } \\
\text { are invited to } \\
\text { give lectures } \\
\text { in psychology } \\
\text { educational } \\
\text { programs ) }\end{array}$ & $\begin{array}{l}\text { No formal role } \\
\text { for psychology } \\
\text { has been } \\
\text { identified }\end{array}$ & $\begin{array}{l}\text { Non- } \\
\text { governmental } \\
\text { organizations } \\
\text { such as Dipla } \\
\text { Sou (meaning } \\
\text { "next to you") } \\
\text { are supported } \\
\text { by the } \\
\text { government } \\
\text { ministry that } \\
\text { deals with } \\
\text { issues of } \\
\text { education. }\end{array}$ & $\begin{array}{l}\text { Continuing } \\
\text { support of } \\
\text { sexuality- and } \\
\text { gender identity- } \\
\text { related mental } \\
\text { health issues for } \\
\text { LGBTQ people } \\
\text { and their families } \\
\text { and communities } \\
\text { Development of a } \\
\text { formal code of } \\
\text { conduct and } \\
\text { guidelines for }\end{array}$ \\
\hline
\end{tabular}




\begin{tabular}{|c|c|c|c|c|c|c|}
\hline & $\begin{array}{l}\text { 2017: Right to } \\
\text { change one's } \\
\text { legal gender } \\
\text { 2018: Right of } \\
\text { same-sex } \\
\text { couples to } \\
\text { adopt and foster } \\
\text { children }\end{array}$ & $\begin{array}{l}\text { discrimination } \\
\text { laws based on } \\
\text { sexual orientation } \\
\text { and gender } \\
\text { identity }\end{array}$ & & & $\begin{array}{l}\text { Both the } \\
\text { Athens and } \\
\text { Thessaloniki } \\
\text { Pride } \\
\text { organizations } \\
\text { are supported } \\
\text { by the current } \\
\text { corresponding } \\
\text { municipal } \\
\text { authorities. }\end{array}$ & $\begin{array}{l}\text { psychologists } \\
\text { working with } \\
\text { LGBTQ people } \\
\text { and their } \\
\text { communities } \\
\text { Greater visibility } \\
\text { and involvement } \\
\text { of psychologists } \\
\text { in the Greek } \\
\text { media when } \\
\text { LGBTQ issues } \\
\text { are discussed } \\
\text { Increased } \\
\text { involvement of } \\
\text { psychologists in } \\
\text { the development } \\
\text { of educational } \\
\text { campaigns and } \\
\text { programmes } \\
\text { within formal } \\
\text { educational } \\
\text { structures (e.g. } \\
\text { university } \\
\text { programs) and } \\
\text { informal ones } \\
\text { (e.g. public talks) }\end{array}$ \\
\hline Colombia & $\begin{array}{l}\text { 2016: Same-sex } \\
\text { marriage } \\
\text { 2016: Adoption } \\
\text { for same-sex } \\
\text { couples }\end{array}$ & No penalization & $\begin{array}{l}\text { (2) The } \\
\text { Colombian } \\
\text { College of } \\
\text { Psychologists } \\
\text { (COLPSIC) } \\
\text { has Division } \\
\text { (or } \\
\text { "disciplinary } \\
\text { field") No. 9, } \\
\text { named } \\
\text { Psychology of } \\
\end{array}$ & $\begin{array}{l}\text { Advising the } \\
\text { government on } \\
\text { adoption by } \\
\text { same-sex } \\
\text { couples. } \\
\text { Publishing of a } \\
\text { document on } \\
\text { sexual } \\
\text { orientation for } \\
\text { psychologists }\end{array}$ & $\begin{array}{l}\text { The District } \\
\text { Department of } \\
\text { Social } \\
\text { Integration } \\
\text { (Secretaría } \\
\text { Distrital de } \\
\text { Integración } \\
\text { Social) funds } \\
\text { LGBTI } \\
\text { community }\end{array}$ & $\begin{array}{l}\text { Provide public } \\
\text { information on } \\
\text { LGBT issues. } \\
\text { Participate in } \\
\text { government } \\
\text { institutions. } \\
\text { Advocate for } \\
\text { better legislation } \\
\text { and support of } \\
\text { LGBT } \\
\text { communities. }\end{array}$ \\
\hline
\end{tabular}




\begin{tabular}{|c|c|c|c|c|c|c|}
\hline & & & $\begin{array}{l}\text { Sexuality. A } \\
\text { number of } \\
\text { this } \\
\text { Division's } \\
\text { activities are } \\
\text { centred on } \\
\text { LGBT issues. }\end{array}$ & $\begin{array}{l}\text { and general } \\
\text { public. } \\
\text { Seminars and } \\
\text { lectures on } \\
\text { LGBT issues. } \\
\text { Defense of } \\
\text { LGBT rights: } \\
\text { "sexual rights } \\
\text { are human } \\
\text { rights." }\end{array}$ & $\begin{array}{l}\text { services in the } \\
\text { city of Bogota. }\end{array}$ & $\begin{array}{l}\text { Educate families, } \\
\text { schools and the } \\
\text { general public on } \\
\text { LGBT issues. }\end{array}$ \\
\hline $\begin{array}{l}\text { South } \\
\text { Africa }\end{array}$ & $\begin{array}{l}\text { 1995: Labour } \\
\text { Relations Act } \\
\text { prohibits } \\
\text { discrimination } \\
\text { on grounds of } \\
\text { sexual } \\
\text { orientation and } \\
\text { marital status } \\
\text { 1996: } \\
\text { Constitutional } \\
\text { protection for } \\
\text { gender } \\
\text { (inclusive of } \\
\text { gender identity) } \\
\text { and sexual } \\
\text { orientation } \\
\text { 1997: Basic } \\
\text { conditions of } \\
\text { Employment } \\
\text { Act and } \\
\text { Employment } \\
\text { Equity Act of } \\
\text { 1998 outlaw } \\
\text { workplace } \\
\text { discrimination, } \\
\text { also on grounds } \\
\text { of gender and }\end{array}$ & $\begin{array}{l}\text { 1998: Anti- } \\
\text { sodomy laws } \\
\text { repealed } \\
\text { 2006-2014: } \\
\text { South African } \\
\text { Blood } \\
\text { Transfusion } \\
\text { Service continues } \\
\text { defending } \\
\text { exclusion of men } \\
\text { who have sex } \\
\text { with men } \\
\text { (MSM), despite } \\
\text { the then existent } \\
\text { evidence for the } \\
\text { safety of blood } \\
\text { transfusion } \\
\text { screening and an } \\
\text { HIV epidemic in } \\
\text { the country that } \\
\text { was not centred } \\
\text { around } \\
\text { homosexual } \\
\text { people } \\
\text { 2006: Jacob } \\
\text { Zuma, prior to } \\
\text { his inauguration }\end{array}$ & $\begin{array}{l}\text { (4) There are } \\
\text { practice } \\
\text { guidelines for } \\
\text { psychologists } \\
\text { working with } \\
\text { LGBTIQA+ } \\
\text { people }\end{array}$ & $\begin{array}{l}\text { 2000: South } \\
\text { African Truth } \\
\text { and } \\
\text { Reconciliation } \\
\text { Commission } \\
\text { hears of } \\
\text { "aversion } \\
\text { (chemical } \\
\text { castration, } \\
\text { shock and } \\
\text { hormonal) } \\
\text { therapy" on } \\
\text { occasion } \\
\text { employed by } \\
\text { health } \\
\text { professionals in } \\
\text { the then South } \\
\text { African } \\
\text { Defence Force } \\
\text { (SADF) during } \\
\text { the apartheid } \\
\text { era (in } \\
\text { particular, } \\
\text { 1971-1989) } \\
\text { 2001: South } \\
\text { African } \\
\text { psychology } \\
\text { represented at }\end{array}$ & $\begin{array}{l}\text { 2009: Victims } \\
\text { of (SOGIE- } \\
\text { based) hate } \\
\text { victimisation } \\
\text { included as } \\
\text { priority target } \\
\text { group in policy } \\
\text { guidelines for } \\
\text { National } \\
\text { Department of } \\
\text { Social } \\
\text { Development } \\
\text { (DSD)-led } \\
\text { Victim } \\
\text { Empowerment } \\
\text { Programme } \\
\text { (VEP) (DSD, } \\
\text { 2009) } \\
\text { 2011: } \\
\text { Department of } \\
\text { Justice-led } \\
\text { National Task } \\
\text { Team (NTT) } \\
\text { launched aimed } \\
\text { at addressing } \\
\text { violence } \\
\text { targeted at } \\
\text { LGBTIQA+ }\end{array}$ & $\begin{array}{l}\text { Sexuality } \\
\text { education at } \\
\text { school continues } \\
\text { to ignore, avoid } \\
\text { or misrepresent } \\
\text { sexual and } \\
\text { gender diversity } \\
\text { Invest more in } \\
\text { intersectional } \\
\text { understandings } \\
\text { and related } \\
\text { vulnerabilities } \\
\text { Develop more } \\
\text { psychosocial } \\
\text { services } \\
\text { affirmative of } \\
\text { sexual and } \\
\text { gender diversity } \\
\text { Develop a } \\
\text { standardized } \\
\text { continuing } \\
\text { professional } \\
\text { development } \\
\text { (CPD) offering in } \\
\text { affirmative } \\
\text { practice with }\end{array}$ \\
\hline
\end{tabular}




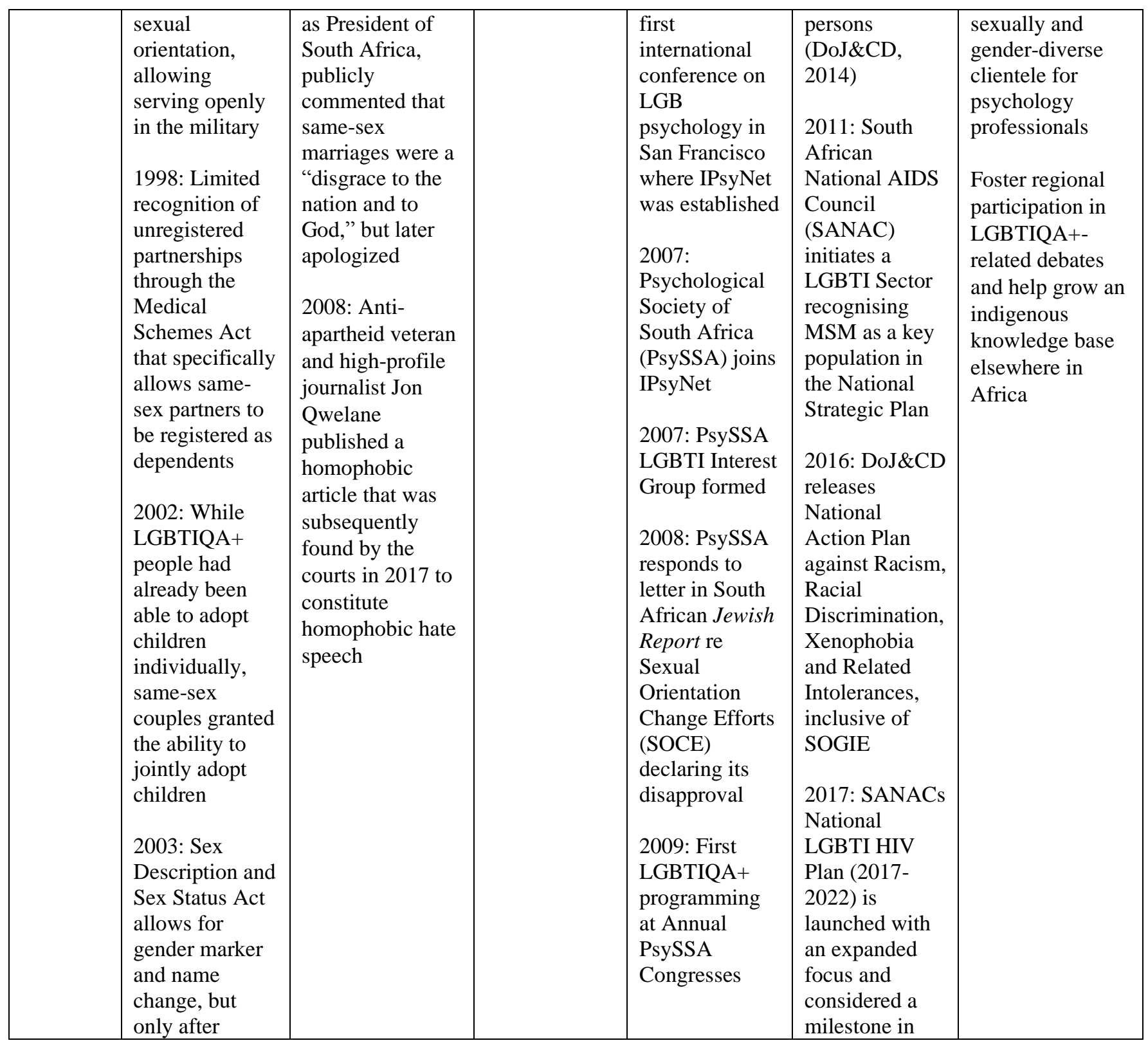




\begin{tabular}{|c|c|c|}
\hline $\begin{array}{l}\text { surgical or } \\
\text { medical gender } \\
\text { reassignment } \\
\text { treatment } \\
\text { 2006: Civil } \\
\text { Union Act } \\
\text { legalizes both } \\
\text { same-sex } \\
\text { marriage and } \\
\text { civil } \\
\text { partnerships } \\
\text { affording the } \\
\text { same benefits } \\
\text { of heterosexual } \\
\text { marriage } \\
\text { 2018: Draft } \\
\text { Prevention and } \\
\text { Combating of } \\
\text { Hate Crimes } \\
\text { and Hate } \\
\text { Speech Bill } \\
\text { includes sexual } \\
\text { orientation, } \\
\text { gender identity } \\
\text { and expression } \\
\text { (SOGIE) }\end{array}$ & $\begin{array}{l}\text { 2010: PsySSA } \\
\text { statement } \\
\text { opposing anti- } \\
\text { homosexuality } \\
\text { legislation in } \\
\text { Uganda (and } \\
\text { subsequent } \\
\text { contribution } \\
\text { early 2014) } \\
\text { 2011: PsySSA } \\
\text { statement re } \\
\text { South Africa's } \\
\text { vote in favour } \\
\text { of removal of } \\
\text { sexual } \\
\text { orientation } \\
\text { from UN } \\
\text { Resolution re } \\
\text { extrajudicial, } \\
\text { summary and } \\
\text { arbitrary } \\
\text { executions } \\
\\
\text { 2012+: } \\
\text { PsySSA is } \\
\text { Friend of the } \\
\text { Court in Jon } \\
\text { Qwelane } \\
\text { homophobic } \\
\text { hate speech } \\
\text { case } \\
\text { 2013: PsySSA } \\
\text { position } \\
\text { statement on } \\
\text { affirmative } \\
\text { psychological } \\
\text { practice for the } \\
\text { sexually and }\end{array}$ & $\begin{array}{l}\text { the country's } \\
\text { response to } \\
\text { HIV, AIDS, } \\
\text { STIs, } \\
\text { and TB, } \\
\text { making it a } \\
\text { world first } \\
\text { 2018: National } \\
\text { Department of } \\
\text { Home Affairs } \\
\text { announces that } \\
\text { officials will } \\
\text { soon undergo } \\
\text { sensitization } \\
\text { training to end } \\
\text { xenophobia } \\
\text { and } \\
\text { homophobia } \\
\text { targeted at } \\
\text { queer asylum } \\
\text { seekers } \\
\text { 2018: South } \\
\text { African Police } \\
\text { Service (SAPS) } \\
\text { finalizes a draft } \\
\text { of their } \\
\text { Standard } \\
\text { Operating } \\
\text { Procedure to } \\
\text { respect, protect } \\
\text { and promote } \\
\text { the rights of } \\
\text { LGBTI+ } \\
\text { people }\end{array}$ \\
\hline
\end{tabular}




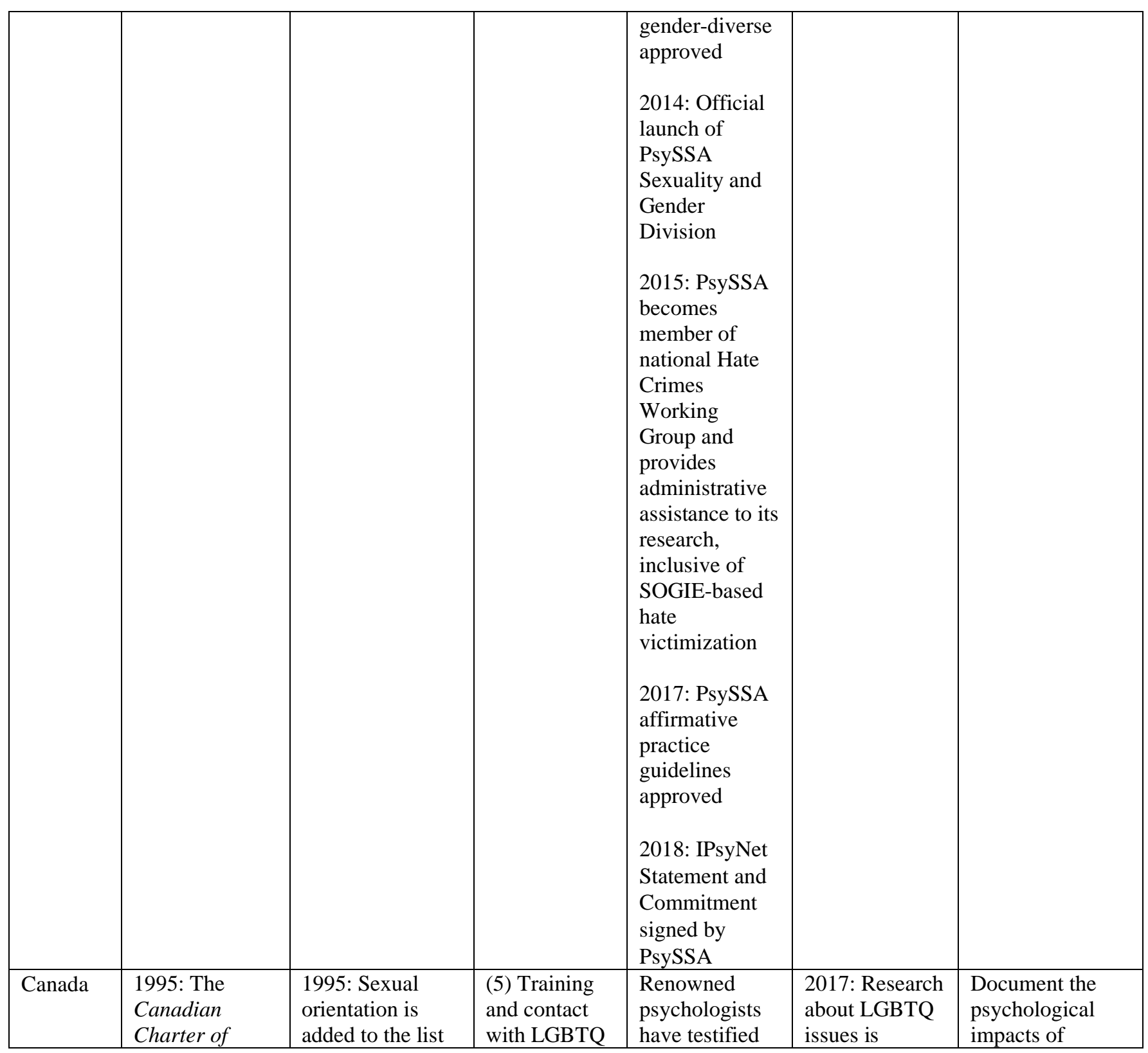




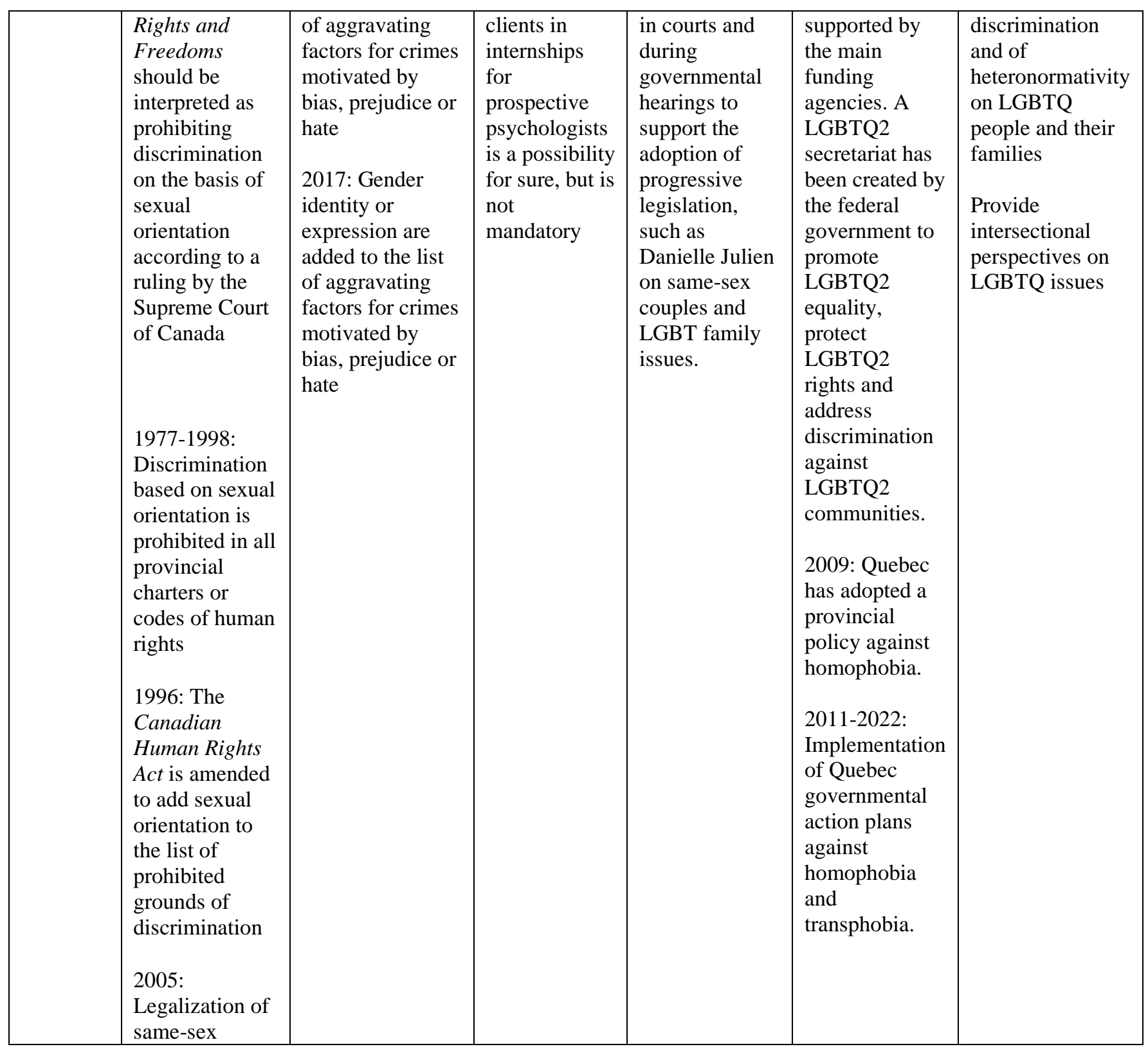




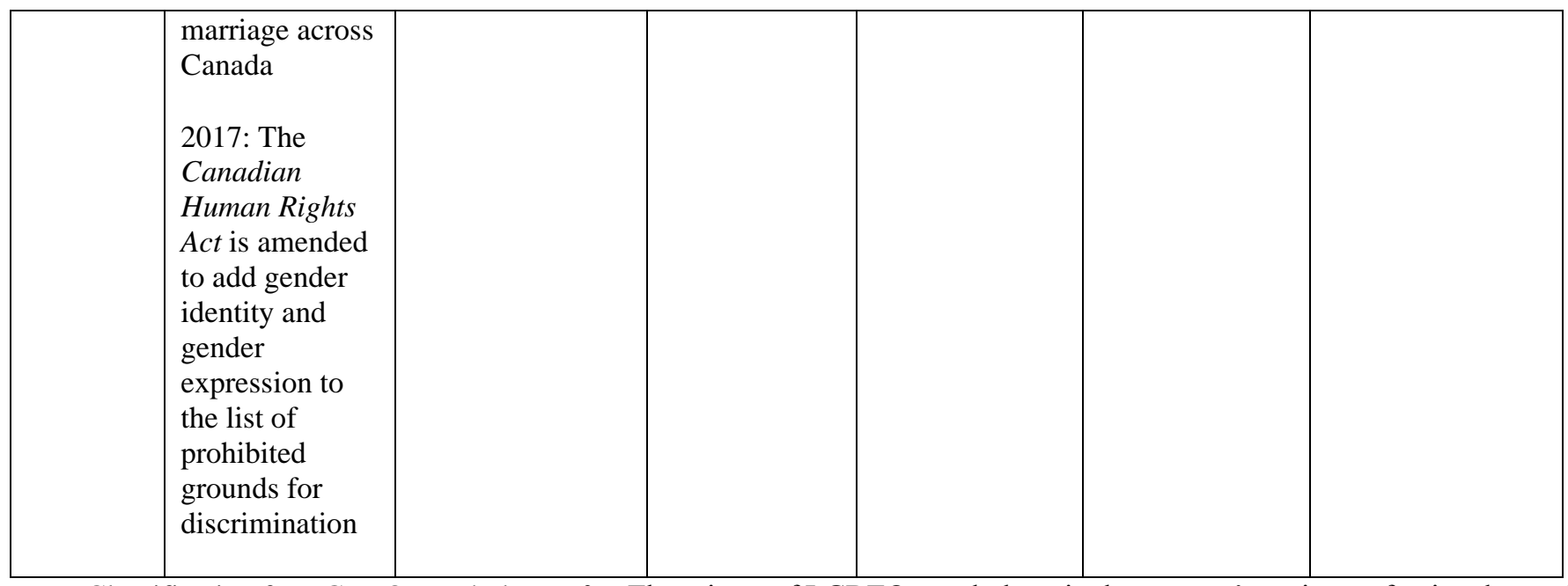

Note: Classification for LGBTQ psychology. $0=$ There is no of LGBTQ psychology in the country's major professional association; $1=$ There is a current discussion about the pertinence of a sexuality section LGBTQ psychology section division in the country's major professional association; $2=$ There is a sexuality or gender division in the country's major professional association; 3 = There is a LGBTQ psychology division in the country's major professional association; $4=$ There are practice guidelines for psychologists working with LGBTQ people; $5=$ There are sanctions for professionals who conduct conversion therapies; 6 = Internships for prospective psychologists include training on and contact with LGBTQ clients 


\section{References}

Academy of Science of South Africa (ASSAf). (2015). Diversity in human sexuality:

Implications for policy in Africa. Retrieved from Pretoria: https://www.assaf.org.za/files/8-JuneDiversity-in-human-sexuality1.pdf

Andersen, R., \& Fetner, T. (2008). Economic inequality and intolerance: Attitudes toward homosexuality in 35 democracies. American Journal of Political Science, 52(4), 942-958. doi:10.1111/j.1540-5907.2008

Anderson, M. Z., \& Croteau, J. M. (2013). Toward an inclusive LGBT psychology of working. In The Oxford handbook of the psychology of working. (pp. 103-126). New York, NY, US: Oxford University Press.

APA. (2010). LGBT activities at the International Congress of Psychology: A programming stream, a symposium, a resolution, and a network. Psychology International. Retrieved from https://www.apa.org/international/pi/2010/10/lgbt-activities.aspx

APA. (2016). Award for Distinguished Early Career Contributions to Psychology in the Public Interest: Anneliese A. Singh. American Psychologist, 71(8), 752-754. doi:10.1037/amp0000087

Ardila, R. (2008). Homosexualidad y psicología (Homosexuality and psychology). Bogotá: Manual Moderno. 
Ardila, R. (2015). History of LGBT issues and psychology in Colombia. Psychology of Sexualities Review, 6 (1), 74-80.

Balsam, K. (2016). 2016 awards for accomplishments in LGBT Psychology. (cover story). Division 44 Newsletter, 31(2), 1-13.

Bereket, T., \& Adam, B. D. (2006). The Emergence of Gay Identities in Contemporary Turkey. Sexualities, 9(2), 131-151.

Betts, E. C. (2013). Fostering LGBTQ advocacy in school psychology as adult education: Shaping attitudes, beliefs, and perceived control. (75), ProQuest Information \& Learning, US.

Biaggio, M., Orchard, S., Larson, J., Petrino, K., \& Mihara, R. (2003). Guidelines for gay/lesbian/bisexual-affirmative educational practices in graduate psychology programs. Professional Psychology: Research and Practice, 34, 548-554. doi:10.1037/07357028.34.5.548

Bidell, M. P. (2016). Mind our professional gaps: Competent lesbian, gay, bisexual, and transgender mental health services. Counselling Psychology Review, 31(1), 67-76.

Boroughs, M. S., Bedoya, C. A., O'Cleirigh, C., \& Safren, S. A. (2015). Toward defining, measuring, and evaluating LGBT cultural competence for psychologists. Clin Psychol, 22, 151-171. doi:10.1111/cpsp. 12098 
Brodnicki, C., \& Savage, T. A. (2004). Addressing LGBT Issues in Psychology Training Programs: One Institution's Effort to Bridge the Gap. Division 44 Newsletter, 20(3), 12-13.

Brotman, S., Ryan, B., Jalbert, Y., \& Rowe, B. (2002). The impact of coming out on health and health care access: the experiences of gay, lesbian, bisexual and two-spirit people. $\mathbf{J}$ Health Soc Policy, 15(1), 1-29. Retrieved from https://www.ncbi.nlm.nih.gov/pubmed/12212930. doi:10.1300/J045v15n01_01

Budge, S. L., Israel, T., \& Merrill, C. R. S. (2017). Improving the lives of sexual and gender minorities: The promise of psychotherapy research. Journal of Counseling Psychology, 64(4), 376-384. doi:10.1037/cou0000215

Burnes, T. R., \& Stanley, J. L. (2017a). Introduction. In Teaching LGBTQ psychology: Queering innovative pedagogy and practice. (pp. 3-15). Washington, DC, US: American Psychological Association.

Burnes, T. R., \& Stanley, J. L. (2017b). Teaching LGBTQ psychology: Queering innovative pedagogy and practice. Washington, DC, US: American Psychological Association.

Buyantueva, R. (2018). LGBT Rights Activism and Homophobia in Russia. J Homosex, 65(4), 456-483. doi:10.1080/00918369.2017.1320167

Canadian Psychological Association. (2018). Policy \& position statements. Retrieved from https://www.cpa.ca/aboutcpa/policystatements 
Case, K. A., \& Lewis, M. K. (2012). Teaching intersectional LGBT psychology: Reflections from historically Black and Hispanic-serving universities. Psychology and Sexuality, 3(3), 260-276. doi:10.1080/19419899.2012.700030

Chamberland, L., Blais, M., Lévy, J. J., Corriveau, P., Richard, G., \& Ryan, B. (2010). Canada. In C. Stewart (Ed.), The Greenwood encyclopedia of LGBT issues worldwide (Vol. 1, pp. 49-71). Santa Barbara, Calif.: Greenwood Press.

Chamberland, L., Lévy, J. J., Kamgain, O., Parvaresh, P., \& Bègue, M. (2018). L’accès à l'égalité des personnes LGBT. Enjeux, luttes et alliances. In F. Saillant \& È. Lamoureux (Eds.), InterReconnaissance : la mémoire des droits dans le milieu communautaire au Québec (pp. 49-77). Québec: Presses de l'Université Laval.

Clarke, V., Ellis, S., Peel, E., \& Riggs, D. W. (2010). Lesbian, gay, bisexual, trans and queer psychology : An introduction. Cambridge: Cambridge University Press.

Clarke, V., \& Peel, E. (2007). From lesbian and gay psychology to LGBTQ psychologies: A journey into the unknown (or unknowable)? In Out in psychology: Lesbian, gay, bisexual, trans and queer perspectives. (pp. 11-35). New York, NY, US: John Wiley \& Sons Ltd.

Cochran, B. N., \& Robohm, J. S. (Producer). (2015). Integrating LGBT competencies into the multicultural curriculum of graduate psychology training programs: Expounding and expanding upon Hope and Chappell's choice points: Commentary on "Extending training in multicultural competencies to include individuals identifying as lesbian, gay, and bisexual: Key choice points for clinical psychology training programs”. 
Copen, C. E., Chandra, A., \& Febo-Vazquez, I. (2016). Sexual behavior, sexual attraction, and sexual orientation among adults aged 18-44 in the United States: Data from the 20112013 National Survey of Family Growth. Retrieved from https://www.cdc.gov/nchs/data/nhsr/nhsr088.pdf

Curtin, N., Hegarty, P., \& Stewart, A. J. (2012). Fostering research collaborations in LGBT psychology: An introduction to the special issue. Psychology and Sexuality, 3(3), 187-194. doi:10.1080/19419899.2012.700020

D’amico, E., Julien, D., Tremblay, N., \& Chartrand, E. (2015). Gay, Lesbian, and Bisexual Youths Coming Out to Their Parents: Parental Reactions and Youths' Outcomes. Journal of GLBT Family Studies, 11(5), 411-437. doi:10.1080/1550428x.2014.981627

DANE. (2018). ¿Cuántos somos? Censo nacional de población y vivienda 2018. Retrieved from https://www.dane.gov.co/index.php/en/estadisticas-por-tema/demografia-ypoblacion/censo-nacional-de-poblacion-y-vivenda-2018/cuantos-somos

De Waal, S., \& Manion, A. (2006). Pride: Protest and Celebration. Johannesburg: Fanele, Jacana Media.

Dianeosis. (2018). World Values Survey, Wave 7. Retrieved from https://www.dianeosis.org/wpcontent/uploads/2018/09/wvs_2018.pdf

Dufalla, J. (2010). Non-Governmental Organizations in Russia: Adapting for success. Vestnik, European Centre for Disease Prevention and Control (ECDC) and World Health Organization (WHO) Regional Office for Europe (WHO/Europe). (2016) Surveillance 
Report: HIV/AIDS surveillance in Europe 2015. Retrieved from http://www.euro.who.int/_data/assets/pdf_file/0019/324370/HIV-AIDS-surveillanceEurope-2015.pdf?ua=1

European Commission (2008). Discrimination in the European Union: Perceptions, experiences and attitudes (Special Eurobarometer 296 / Wave 69.1 - TBS opinion \& social). Retrieved from http://ec.europa.eu/commfrontoffice/publicopinion/archives/ebs/ebs_296_en.pdf

Feugé, É. A., Cossette, L., Cyr, C., \& Julien, D. (2019). Parental involvement among adoptive gay fathers: Associations with resources, time constraints, gender role, and child adjustment. Psychology of Sexual Orientation and Gender Diversity, 6(1), 1-10. doi:http://dx.doi.org/10.1037/sgd0000299

Forsell, S., Swift-Erslev, N., Davis, C., Ruth, R., Zucker, A., Glezen, S., . . Schlittler, R. L. (2017). Quality and equality: An interdisciplinary graduate program to develop agents of change in LGBT health. In R. Ruth \& E. Santacruz (Eds.), LGBT psychology and mental health: Emerging research and advances. (pp. 327-265). Santa Barbara, CA, US: Praeger/ABC-CLIO.

Fortier, C., \& Julien, D. (2003). Les psychothérapies de conversion pour les personnes gaies, lesbiennes et bisexuelles: état de la question et enjeu éthique. Canadian Psychology/Psychologie canadienne, 44(332-350).

Francis, D.A., \& Msibi, T. (2011). Teaching about heterosexism: Challenging homophobia in South Africa. Journal of LGBT Youth, 8(2), 157-173. doi: 10.1080/19361653.2011.553713 
Fygetakis, L. M. (1997). Greek American lesbians: Identity odysseys of honorable good girls. In B. E. Green (Ed.), Ethnic and cultural diversity among lesbians and gay men (pp. 152-190): Thousand Oaks: Sage Publications, Inc.

Gevisser, M., \& Cameron, E. (1995). Defiant desire : Gay and lesbian lives in South Africa. New York: Routlege.

Glassgold, J. M., \& Drescher, J. (2007). Activism and LGBT psychology: An introduction. Journal of Gay \& Lesbian Psychotherapy, 11(3-4), 1-8. doi:10.1300/J236v11n03_01

Gonzáles, J. M., Ardila, R., Guerrero, P., Penagos, G., \& Useche, B. (2004). Colombia. In R. Francœur \& R. Noonan (Eds.), The continuum complete international incyclopedia of sexuality (pp. 210-226). New York: The Continuun International Publishing Group Ltd.

Gulevich O., Osin E., Isaenko N., \& Brainis L. (2018) Scrutinizing homophobia: A model of perception of homosexuals in Russia, Journal of Homosexuality, 65 (13), 1838-1866.

Healey, D. (2002). Homosexual existence and existing socialism: New light on the repression of male homosexuality in Stalin's Russia. GLQ: A Journal of Lesbian and Gay Studies, 8(3), 379-378. doi:10.1215/10642684-8-3-349

Hoad, N. K., Martin, K., \& Reid, G. (2005). Sex \& Politics in South Africa. Cape Town: Double Storey Books.

Hoffman, R. J. (1980). Some cultural aspects of Greek male homosexuality. J Homosex, 5(3), 217-226. doi:10.1300/J082v05n03_05 
Horne, S., Maroney, M. R., Zagryazhskaya, E. A., \& Koven, J. (2017). Attitudes toward gay and lesbian individuals in Russia: An exploration of the interpersonal contact hypothesis and personality factors. Psychology in Russia: State of the Art, 10(2), 21-34. doi:Psychology in Russia: State of the Art

Horne, S. G., \& White, L. (2019). LGBT mental health in Russia. In N. Nakamura (Ed.), LGBT mental health: Global perspectives and experiences: In Press.

Hope, D. A., \& Chappell, C. L. (2015). Extending training in multicultural competencies to include individuals identifying as lesbian, gay, and bisexual: Key choice points for clinical psychology training programs. Clinical Psychology: Science and Practice, 22(2), 105-118.

ILGA, Carroll, A., \& Mendos, L. R. (2017). State-sponsored homophobia 2017: A world survey of sexual orientation laws: Criminalisation, protection, and recognition. International Lesbian, Gay, Bisexual, Trans and Intersex Association. Retrieved from Geneva: https://ilga.org/downloads/2017/ILGA_State_Sponsored_Homophobia_2017_WEB.pdf

ILGA, Chiam, Z., Duffy, S., \& González Gil, M. (2017). Trans legal mapping report 2017: Recognition before the law. International Lesbian, Gay, Bisexual, Trans and Intersex Association. Retrieved from Geneva: https://ilga.org/downloads/ILGA_Trans_Legal_Mapping_Report_2017_ENG.pdf IPsyNet. (2018). IPsyNet Statement on LGBTIQ+ Concerns. International Psychology Network for Lesbian, Gay, Bisexual, Transgender and Intersex Issues. Retrieved from http://www.apa.org/ipsynet/advocacy/policy/statement-english.pdf 
Isaacs, G., \& McKendrick, B. (1992). Male homosexuality in South Africa : Identity formation, culture, and crisis. Cape Town ; New York: Oxford University Press.

Isaev D ( 2016) Исаев Д. Д. Деконструкция гетеронормативной матрицы (Deconstruction of heteronormative matrix) // Психология. Журнал высшей школы экономики. - 2016. T.13. №1. C. 9-26.

Judge, M., Manion, A., \& De Waal, S. (2008). To have \& to hold: The making of same-sex marriage in South Africa. Johannesburg: Fanele Jacana Media.

Judge, M., \& Nel, J. A. (2007). Ensuring the Victims Service Charter works for lesbian, gay, bisexual and transgender people. Submission to the National Department of Justice. In. Pretoria: Submission to the National Department of Justice.

Judge, M., \& Nel, J. A. (2017). Psychology and hate speech: a critical and restorative encounter. South African Journal of Psychology, 48(1), 15-20.

doi:10.1177/0081246317728165

Julien, D., \& Chartrand, É. (2005). Recension des études utilisant un échantillon probabiliste sur la santé des personnes gaies, lesbiennes et bisexuelles. Canadian Psychology/Psychologie canadienne, 46(4), 235-250. doi:10.1037/h0087031

Julien, D. (2008). Homoparentalité. In J. J. Lévy \& A. Dupras (Eds.), Questions de sexualité au Québec (pp. 171-181). Montreal: Éditions Liber. 
Julien, D., \& Chartrand, É. (1997). La psychologie familiale des gais et des lesbiennes: perspectives de la tradition scientifique nord-américaine. Sociologie et Sociétés, 29(1), 71-81. doi:10.7202/001369ar

Kimmel Lectures on LGBT Psychology in China. (2005). Division 44 Newsletter, 21(3), 4-4.

Kon, I. S. (2003). Лунный свет на заре. Лики и маски однополой любви [Faces and masks of same sex love. Moonlight at dawn]. Moscow: Ulymp.

Kondakov, A. (1993). Resisting the silence: The use of tolerance and equality arguments by gay and lesbian activist groups in Russia. Canadian Journal of Law \& Society/La Revue Canadienne Droit et Société, 28(3), 403-424. doi:10.1017/cls.2013.3

Levada Center. (2015). Homophobia. Retrieved from http://www.levada.ru/en/2015/06/10/homophobia/

Lucas-Carr, C. B., \& Krane, V. (2011). What is the T in LGBT? Supporting transgender athletes through sport psychology. The Sport Psychologist, 25(4), 532-548.

Lunin, I. I. (2017). Striving for LGBTQ rights in Russian psychology and society: A personal narrative. Psychology in Russia: State of the Art, 10(2), 35-41. doi:10.11621/pir.2017.0203

Lytle, M. C., Rodriguez, E. M., Vaughan, M. D., \& Shmerler, D. L. (2014). Working with LGBT individuals: Incorporating positive psychology into training and practice. Psychology of Sexual Orientation and Gender Diversity, 1(4), 335-347. doi:10.1037/sgd0000064 
Magongo, B. (2016). Enhancing civil society participation in the South African development agenda: The role of civil society organisations. Parktown: The National Development Agency.

Malouf, M. (2013). Content analysis of the LGBT counseling literature: 2000-2009. (74), ProQuest Information \& Learning, US.

Mattey, E., McCloughan, L. J., \& Hanrahan, S. J. (2014). Anti-vilification programs in adolescent sport. Journal of Sport Psychology in Action, 5(3), 135-146. doi:10.1080/21520704.2014.925528

Matza, A. R., Sloan, C. A., Kauth, M. R., \& DeBakey, M. E. (2015). Quality LGBT health education: A review of key reports and webinars. Clinical Psychology: Science and Practice, 22(2), 127-144. doi:10.1111/cpsp.12096

Medico, D. (2016). Repenser le genre : une clinique avec les personnes trans. Switzerland: Georg éditeur.

Meyer, I. H. (2014). Minority stress and positive psychology: Convergences and divergences to understanding LGBT health. Psychology of Sexual Orientation and Gender Diversity, 1(4), 348-349. doi:10.1037/sgd0000070

Mitchell, Y., \& Nel, J. A. (2017). The Hate and Bias Crimes Monitoring Form Project: January 2013 to September 2017. Retrieved from Johannesburg: http://hcwg.org.za/wpcontent/uploads/2018/02/Report-Hate-Bias-Crimes-Monitoring-Form-Project-SCREEN.pdf 
Moane, G. (2013). Sexual Diversity and Gender Issues Special Interest Group. The Irish Journal of Psychology, 34(3-4), 163-168. doi:10.1080/03033910.2013.861762

Moeti, K. (2012). Understanding differences between civil society and civil society organisations. Retrieved from http://www.ngopulse.org/blogs/understanding-differencesbetween-civil-society-and-civil-society-organisations

Morales, E. S. (1996). Gender roles among Latino gay and bisexual men: Implications for family and couple therapy. In J. Laird \& R. J. Green (Eds.), Lesbians and gays in couples and families : A handbook for therapists (pp. 272-297). San Francisco: Jossey-Bass Publishers.

Moreno, A., Herazo, E., Oviedo, H., \& Campo-Arias, A. (2015). Measuring homonegativity: psychometric analysis of Herek's attitudes toward lesbians and gay men scale (ATLG) in Colombia, South America. J Homosex, 62(7), 924-935. doi:10.1080/00918369.2014.1003014

Moreno, A., \& Das Nair, R. (2016). Guest editorial: Lesbian, Gay, Bisexual, Transgender and Intersex (LGBTI) Psychology: International perspectives (volume 2). Psychology of Sexualities Review, 7(1), 11-13.

Moreno, A., Koch, J., \& dickey, l. (2016). Lesbian, gay, bisexual, transgender, and intersex programming at the 31st International Congress of Psychology: Diversity in harmony. Psychology of Sexualities Review, 7, 92-98. 
Moreno, A., Laoch, A., \& Zasler, N. (2017). Changing the culture of neurodisability through language and sensitivity of providers: Creating a safe place for LGBTQIA+ people.

NeuroRehabilitation, 41(2), 375-393. doi:10.3233/NRE-172187

Murphy, J (2017) Canada has quietly granted asylum to LGBT Chechens. Retrieved from BBC https://www.bbc.com/news/world-us-canada-41075528

Nduna, M., Mthombeni, A., Mavhandu-Mudzusi, A.H., \& Mogotsi, I. (2017). Studying sexuality: LGBTI experiences in institutions of higher education in Southern Africa. South African Journal of Higher Education, 31(4), 1-13. doi: 10.20853/31-4-1330

Nel, J. A. (2004). Human rights abuses of LGBTI people in South African prisons. LGBTISpecific Mental Health Needs and the Importance of LGBTI-affirmative Health Services. Jali Commission of Inquiry into the Department of Correctional Services. Written submission. In. Pretoria: Unisa Centre for Applied Psychology.

Nel, J. A. (2008). Sexual orientation must be accepted - PsySSA. SA Jewish Report, 02-09 May 2008. . Retrieved from www.sajewishreport.co.za

Nel, J. A. (2009a). Same-sex sexuality and health: Current psycho-social scientific research in South Africa. Paper presented at the 15th National Conference of the Psychological Society of South Africa (PsySSA), Cape Town.

Nel, J. A. (2009b). Same-sex sexuality and health: Psychosocial scientific research in South Africa. In V. Reddy, T. Sandfort, \& L. Rispel (Eds.), From social silence to social science: 
Same-sex sexuality, HIV \& AIDS and gender in South Africa (pp. 32-50). Cape Town: HSRC Press.

Nel, J. A. (2014). South African psychology can and should provide leadership in advancing understanding of sexual and gender diversity on the African continent. South African Journal of Psychology, 44(2), 145-148. doi:10.1177/0081246314530834

Nel, J. A. (2018). Launch of landmark PsySSA guidelines on sexual and gender diversity welcomed. PsyTalk, 2.Retrieved from http://psytalk.psyssa.com/launch-landmark-psyssaguidelines-sexual-gender-diversity-welcomed-widely/

Nel, J. A., \& Judge, M. (2008). Hate Crime in South Africa: Issues, challenges and strategies for action. Submission to the National Prosecuting Authority. In. Pretoria: UNISA Centre for Applied Psychology \& OUT LGBT Well-Being.

Newell, M. L., Nastasi, B. K., Hatzichristou, C., Jones, J. M., Schanding, G. T., \& Yetter, G. (2010). Evidence on multicultural training in school psychology: Recommendations for future directions. School Psychology Quarterly, 25, 249-278. doi:10.1037/a0021542

Noriega, A. (2012). Unheard Voices, Untold Stories: The Multiple Identities that Comprise LGBT Psychology and its Implications for Practice, Research, and Education. (cover story). Division 44 Newsletter, 28(3), 1-2.

Nussbaum, M. C. (2002). Other times, other places: Homosexuality in ancient Greece. Annual of Psychoanalysis, 30, 9-22. 
Odendaal, A., \& Nel, J. A. (In Press). Towards LGBTI Health and Well-being: Reflections on a University of South Africa Community Engagement Project. In Kiguwa P. e. a. (Ed.), Destabilising heteronormativity in higher education in Southern Africa. Pretoria: University of South Africa Press.

Ordre des Psychologues du Québec. (2012). Les interventions qui visent à changer l'orientation sexuelle [Press release]. Retrieved from https://www.ordrepsy.qc.ca/documents/26707/63191/Les+interventions+qui+visent+à+changer+1'orientati on+sexuelle/b57fed59-38cb-4496-8976-2a5b832cf035

Papadaki, V., Plotnikof, K., Gioumidou, M., Zisimou, V., \& Papadaki, E. (2015). A comparison of attitudes toward lesbians and gay men among students of helping professions in Crete, Greece: The cases of social work, psychology, medicine, and nursing. J Homosex, 62(6), 735-762. doi:10.1080/00918369.2014.998956

Paprocki, C. M. (2014). When personal and professional values conflict: Trainee perspectives on tensions between religious beliefs and affirming treatment of LGBT clients. Ethics \& Behavior, 24(4), 279-292. doi:10.1080/10508422.2013.860029

Percy, W. A. (2005). Reconsiderations about Greek homosexualities. Journal of Homosexuality, 49(3), 13-61.

Petit, M.-P., Julien, D., \& Chamberland, L. (2018). Interlinkages between parental and trans trajectories: A life course perspective. Psychology of Sexual Orientation and Gender Diversity, 5(3), 371-386. doi:10.1037/sgd0000280 
Phellas, C. N. (2001). Zorba the 'gay' Anglo-Greek: Negotiating cultural and sexual identities. Lesbian \& Gay Psychology Review, 2(3), 77-82.

Pollitt, A. M., Brimhall, A. L., Brewster, M. E., \& Ross, L. E. (2018). Improving the field of LGBTQ psychology: Strategies for amplifying bisexuality research. Psychology of Sexual Orientation and Gender Diversity, 5(2), 129-131. doi:10.1037/sgd0000273

Pope, M. (2011). Awards 2011: Celebrating 25 Years of LGBT Psychology. Division 44 Newsletter, 27(3), 6-8.

Psychological Society of South Africa (PsySSA). (2010). Constitution of the Psychological Society of South Africa. Retrieved from https://www.psyssa.com/wpcontent/uploads/2015/11/PsySSAConstitution2015.pdf

Psychological Society of South Africa (PsySSA). (2013). Sexual and gender diversity position statement. Retrieved from https://www.psyssa.com/wpcontent/uploads/2015/12/PsySSA_position_statement_sexual_gender.pdf

Psychological Society of South Africa (PsySSA). (2017). Practice guidelines for psychology professionals working with sexually and gender-diverse people. Retrieved from https://www.psyssa.com/practice-guidelines-for-psychology-professionals-working-with-sexually-and-genderdiverse-people/

Psychological Society of South Africa (PsySSA), Nel, J. A., Lubbe-De Beer, C., \& Schlittler, R. (2010). An Open Statement from the Psychological Society of South Africa to the People and Leaders of Uganda Concerning The Anti-Homosexuality Bill 2009 [Press release]. 
Retrieved from https://www.psyssa.com/wp-content/uploads/2015/12/PsySSA-Press-release-statementcombined_25022010.pdf

Psychological Society of South Africa (PsySSA), Nel, J. A., Lubbe-De Beer, C., \& Schlittler, R. (2011). An Open Statement from the Psychological Society of South Africa Concerning Vote of the South African Representatives at the Third Committee of the United Nations General Assembly on 16 November 2010 [Press release]. Retrieved from https://www.psyssa.com/wp-content/uploads/2015/12/PsySSA-Press-release-statementcombined_25022010.pdf

Psychological Society of South Africa (PsySSA), Nel, J. A., \& McLachlan, C. (2018). An Open Statement from the Psychological Society of South Africa Sexuality and Gender Division: Debates in the Dutch Reformed Church re Sexual Orientation and Misrepresentation of Pedophilic Disorder as Comparable to Same-sex Sexual Orientation. Retrieved from https://www.psyssa.com/wp-content/uploads/2018/10/PsySSA-SGD-open-statement-reDutch-Reformed-Church-debate-re-sexual-orientation_fin.pdf.

Reddy, V., Sandfort, T., \& Rispel, L. (2009). Same-sex sexuality, HIV \& AIDS and gender in South Africa. In Proceedings of an International Conference on Gender, Same-sex sexuality and HIV/ AIDS, 9 - 11 May 2007. Pretoria: Human Sciences Research Council Press.

Republic of South Africa. (1996). Constitution of the Republic of South Africa. Act 108 of 1996. Pretoria: Government Printer. 
Riggs, D. W. (2013). EDITORIAL: RETROSPECTIVE. Gay and Lesbian Issues and Psychology Review, 9(1), 1-2.

Rivers, I. (2007). Bringing LGBTQ Psychology into mainstream practice. In Out in psychology: Lesbian, gay, bisexual, trans and queer perspectives. (pp. 332-334). New York, NY, US: John Wiley \& Sons Ltd.

Rivkin-Fish, M., \& Hartblay, C. (2014). When Global LGBTQ Advocacy Became Entangled with New Cold War Sentiment: A Call for Examining Russian Queer Experience. The Brown Journal of World Affairs, XXI(1), 95-111.

Russell, S. T., \& Horn, S. S. (2017). Sexual orientation, gender identity, and schooling the nexus of research, practice, and policy. New York (N.Y.): Oxford university press.

Salazar, J. E. (2015). The influences of LGBT curriculum on adolescent homophobia, biphobia \& transphobia. (1598321 M.A.), University of Colorado at Denver, Ann Arbor. Retrieved from https://search.proquest.com/docview/1720252312?accountid=14719 http://openurl.uquebec.ca:9003/uqam?url_ver=Z39.882004\&rft_val_fmt=info:ofi/fmt:kev:mtx:dissertation\&genre=dissertations+\%26+theses\&sid=ProQ:GenderWatc

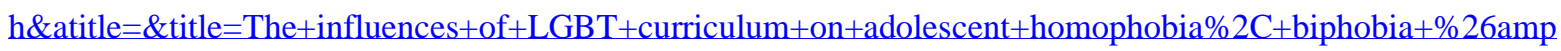
$\% 3 B+$ transphobia\&issn $=\&$ date $=2015-01-$

01\&volume $=\&$ issue $=\&$ spage $=\& a u=$ Salazar\%2C + Jason + Eric \&isbn $=9781339027890 \&$ jtitle=\&btitle=\&rft $\_i d=i n$ fo:eric/\&rft_id=info:doi//GenderWatch database.

Schlittler, R. L., Grey, M. J., \& Popanz, T. (2017). LGBT health and LGBT psychology: emerging policy issues. In R. Ruth \& E. Santacruz (Eds.), LGBT psychology and mental 
health: Emerging research and advances. (pp. 217-235). Santa Barbara, CA, US: Praeger/ABC-CLIO.

Shang, Y.-T. (2013). Cultural competence of sport psychology consultants in Taiwan in working with LGBT athletes. (3592835 Ph.D.), The University of North Carolina at Greensboro, Ann Arbor. Retrieved from https://search.proquest.com/docview/1437644026?accountid=14719 http://openurl.uquebec.ca:9003/uqam?url_ver=Z39.88-

2004\&rft_val_fmt=info:ofi/fmt:kev:mtx:dissertation\&genre=dissertations+\%26+theses\&sid=ProQ:GenderWatc h\&atitle $=\&$ title $=$ Cultural + competence + of + sport + psychology + consultants + in + Taiwan + in + working + with + LGB $\mathrm{T}+$ athletes $\&$ issn $=\&$ date $=2013-01-01 \&$ volume $=\&$ issue $=\&$ spage $=\& a u=$ Shang $\% 2 \mathrm{C}+\mathrm{Ya}-$ Ting\&isbn=9781303344343\&jtitle=\&btitle=\&rft_id=info:eric/\&rft_id=info:doi/ GenderWatch database.

Shuster, S. (2018) Targeted in Chechnya for being gay, still not safe in Europe. Retrieved from Time, http://time.com/chechnya-movsar/

Smith, M. (2011). Canada: The power of institutions In M. Tremblay, D. Paternotte, \& C. Johnson (Eds.), The lesbian and gay movement and the state : comparative insights into a transformed relationship (pp. 73-88). Farnham: Ashgate.

Spiliotis, D., Brown, D., \& Coyle, A. (2011). The psychotherapeutic tales of five gay men in Greece. Psychology of Sexuality Review, 2(1), 25-40.

Stanley, J. L., Burnes, T. R., \& Weinstock, J. S. (2017). Teaching the history of LGBTQ psychology. In Teaching LGBTQ psychology: Queering innovative pedagogy and practice. (pp. 17-38). Washington, DC, US: American Psychological Association. 
Stevenson, M. R. (2005). Uncle Sam Needs You: Public Policy and LGBT Psychology. Division 44 Newsletter, 21, 12-15.

Susset, F. (2014). Vulnérabilité et stigmatisation des enfants non normatifs dans l'expression de leur genre. Revue Québécoise de Psychologie, 3.

Susset, F. (2018). Between a rock and a hard place : the experience of parents of gendernonconforming boys. In E. J. Meyer \& A. Pullen-Sansfaçon (Eds.), Supporting transgender $\&$ gender-creative youth : schools, families, and communities in action (Revised edition). New York: Peter Lang.

Talero, M. (1997). Travestismo: una identidad paródica (Unpublished disseration). Universidad Nacional de Colombia, Bogotá, Colombia.

Talero, M. (2006). La utopía del ser. In J. F. Serrano (Ed.), Otros cuerpos, otras sexualidades (pp. 34-53). Bogotá: Instituto Pensar.

Talero, M. (2008). La deconstrucción del género: un derecho. In B. Espinosa (Ed.), Cuerpos y diversidad sexual : aportes para la igualdad y el reconocimiento (pp. 88-95). Bogotá: Pontificia universidad Javeriana.

ToVima Team. (2018). Amvrosios was found innocent for saying 'spit on them' against

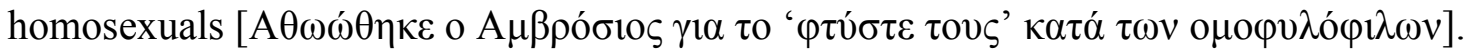
Retrieved from https://www.tovima.gr/2018/03/15/society/athwwthike-o-ambrosios-gia-to-ftyste-toys-katatwn-omofylofilwn/ 
Tremblay, M. (2015). Quebec and sexual diversity In M. Tremblay (Ed.), Queer mobilizations : social movement activism and Canadian public policy (pp. 106-124). Vancouver, BC: UBC Press.

Tsilikin, D. (2002). Вопрос ниже пояса [Questions from the waist down]. Saint Petersburg, Russia: Azbuka-klassika.

UNISA Centre for Applied Psychology (UCAP). (2008). 1998-2008 Commemorative report on 10 years of existence. Retrieved from http://uir.unisa.ac.za/handle/10500/25053

Useche, B. (2005a). Medicalización, erotismo y diversidad sexual: una crítica sexológica al DSM-IV-TR (I parte) - Medicalization, eroticism and sexual diversity: a sexological critique of the DSM-IV-TR (I part). Sexología Integral, 2(1), 36-42.

Useche, B. (2005b). Medicalización, erotismo y diversidad sexual: una crítica sexológica al DSM-IV-TR (II parte)-Medicalization, eroticism and sexual diversity: a sexological critique of the DSM-IV-TR (II part). Sexología Integral, 2(2), 24-32.

Ussher, J. M. (2009). Heterocentric practices in health research and health care: Implications for mental health and subjectivity of LGBTQ individuals. Feminism \& Psychology, 19(4), 561-567. doi:10.1177/0959353509342933

Van Zyl, M., \& Steyn, M. (2005). Performing queer: Shaping sexualities 1994-2004, Vol 1 (Social Identities South Africa). Cape Town: Kwela Books. 
Vaughan, M. D., Parent, M. C., Tilghman, J. D., Miles, J., Lee, H. S., \& Prokhorets, S. (2014). A content analysis of LGBT-themed positive psychology articles. Psychology of Sexual Orientation and Gender Diversity, 1(4), 313-324. doi:10.1037/sgd0000060

Vaughan, M. D., \& Rodriguez, E. M. (2014). LGBT strengths: Incorporating positive psychology into theory, research, training, and practice. Psychology of Sexual Orientation and Gender Diversity, 1(4), 325-334. doi:10.1037/sgd0000053

Vecho, O., \& Schneider, B. (2015). Attitudes envers l'homoparentalité: une comparaison entre psychologues français et québécois. Canadian Journal of Behavioural Science/Revue canadienne des sciences du comportement, 47(1), 102-112. doi:10.1037/a0037607

Veltman, A., \& Chaimowitz, G. (2014). Mental health care for people who identify as lesbian, gay, bisexual, transgender, and (or) queer. The Canadian Journal of Psychiatry, $59(11), 1-7$.

Victor, C. J., \& Nel, J. A. (2016). Lesbian, gay, and bisexual clients' experience with counselling and psychotherapy in South Africa: Implications for affirmative practice. South African Journal of Psychology, 46(3), 351-363. doi:10.1177/0081246315620774

Victor, C. J., \& Nel, J. A. (2017). Developing an affirmative position statement on sexual and gender diversity for psychology professionals in South Africa. Psychology in Russia: State of the Art, 10(2), 87-102. doi:10.11621/pir.2017.0206 
Victor, C. J., Nel, J. A., Lynch, I., \& Mbatha, K. (2014). The Psychological Society of South Africa sexual and gender diversity position statement: Contributing towards a just society. South African Journal of Psychology, 44(3), 292-302. doi:10.1177/0081246314533635

Voultsos, P., Zymvragou, C. E., Raikos, N., \& Spiliopoulou, C. C. (2018). Lesbians' experiences and attitudes towards parenthood in Greece. Cult Health Sex, 1-13. doi:10.1080/13691058.2018.1442021

Vyncke, J., Julien, D., Jouvin, E., \& Jodoin, E. (2014). Systemic heterosexism and adjustment among adolescents raised by lesbian mothers. Canadian Journal of Behavioural Science / Revue Canadienne Des Sciences Du Comportement, 46(3), 375-386. doi:10.1037/a0034663

Vyncke, J., Julien, D., Ryan, B., Jodoin, E., \& Jouvin, E. (2008). Familles homoparentales : état des lieux In C. Parent, S. Drapeau, M. Brousseau, \& E. Pouliot (Eds.), Visages multiples de la parentalité (pp. 185-122). Québec: Les Presses de l’Université du Québec.

Walinsky, D. S. (2013). Factors impacting clinical and counseling psychology students conducting research with lgbt populations. (74), ProQuest Information \& Learning, US.

Wallace, B. C., \& Santacruz, E. (2017a). Addictions and substance abuse in the LGBT community: New approaches. In R. Ruth \& E. Santacruz (Eds.), LGBT psychology and mental health: Emerging research and advances. (pp. 153-175). Santa Barbara, CA, US: Praeger/ABC-CLIO. 
Wallace, B. C., \& Santacruz, E. (2017b). Challenges in moving forward toward the resolution, reduction, and elimination of health disparities for LGBT populations. In R. Ruth \& E. Santacruz (Eds.), LGBT psychology and mental health: Emerging research and advances. (pp. 197-215). Santa Barbara, CA, US: Praeger/ABC-CLIO.

Wallace, B. C., \& Santacruz, E. (2017c). Health disparities and LGBT populations. In R. Ruth \& E. Santacruz (Eds.), LGBT psychology and mental health: Emerging research and advances. (pp. 177-195). Santa Barbara, CA, US: Praeger/ABC-CLIO.

Wallace, B. C., \& Santacruz, E. (2017d). LGBT psychology and ethnic minority perspectives: Intersectionality. In LGBT psychology and mental health: Emerging research and advances. (pp. 87-108). Santa Barbara, CA, US: Praeger/ABC-CLIO.

Warner, L. R., \& Shields, S. A. (2013). The Intersections of Sexuality, Gender, and Race: Identity Research at the Crossroads. Sex Roles, 68(11-12), 803-810. doi:http://dx.doi.org/10.1007/s11199-013-0281-4

Weinstock, J. S. (2003). Lesbian, gay, bisexual, transgender, and intersex issues in the psychology curriculum. In Teaching gender and multicultural awareness: Resources for the psychology classroom. (pp. 285-297). Washington, DC, US: American Psychological Association.

Weir, C., \& Piquette, N. (2018). Counselling transgender individuals: Issues and considerations. Canadian Psychology/Psychologie canadienne, 59(3), 252-261. 
Wheeler, N. L., Mitchell, A., Budge, G., \& Hunt, A. (2017). Community psychology placements for DClinPsy trainees: An example of working with an LGBT+ charity. Clinical Psychology Forum(299), 9-14.

Whitman, J. S., Horn, S. S., \& Boyd, C. J. (2007). Activism in the schools: Providing LGBTQ affirmative training to school counselors. Journal of Gay \& Lesbian Psychotherapy, 11(3-4), 143-154. doi:10.1300/J236v11n03_08

Yashenkova, D., \& Kirichenko, K. (2016). Violation of transgender people's rights in Russia: Research results. Saint Petersburg: Transgender Legal Defense Project. Retrieved from pravo-trans.eu/files/violation_of_the_rights_of_transgender_people_in_Russia-en.pdf Zervoulis, K. (2016). The Greek context in relation to homosexuality, homophobia, and gay identity and community. Psychology of Sexualities Review, 7(1), 15-28.

Zervoulis, K., Lyons, E., \& Dinos, S. (2015). Stigma and self-esteem across societies: Avoiding blanket psychological responses to gay men experiencing homophobia. BJPsych Bull, 39(4), 167-173. doi:10.1192/pb.bp.114.048421 